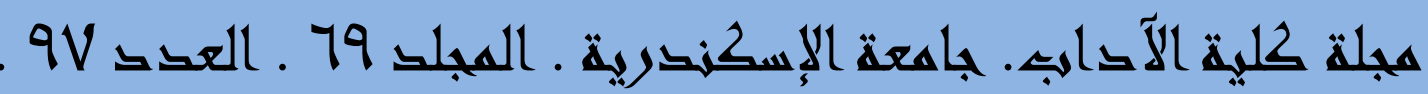

استخدامات الأراضي على الطريق الدائري الثاني بالمدينة المنورة إلى عام ؟ب؟ ا هـ

$$
\begin{aligned}
& \text { دكتور / عبد الله بن حمود الأحمدي } \\
& \text { استاذ مساعد بقسم العلوم الاجتماعية } \\
& \text { كلية الآداب والعلوم الإنسانية } \\
& \text { جامعة طيبة }
\end{aligned}
$$

$$
\begin{aligned}
& \text { دكتور / علي فهمي الجندي } \\
& \text { أستاذ مساعد بقسم العلوم الاجتماعية } \\
& \text { كلية الآداب والعلوم الإنسانية } \\
& \text { جامعة طيبة }
\end{aligned}
$$

ه \& \& 


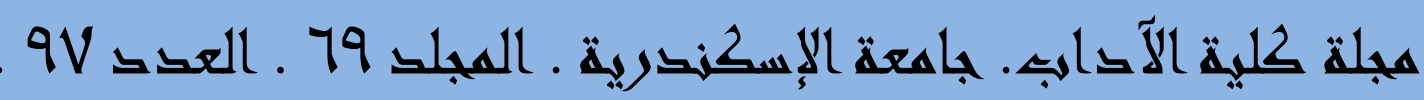

\section{استخدامات الأراضي على الطريق الدائري الثاني بالمدينة المنورة}

\section{مقدمة الدراسة:}

تعد المدينة المنورة واحدة من المدن التاريخية القديمة في شبه الجزيرة العربية وكانت

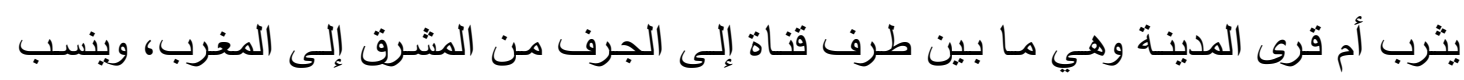

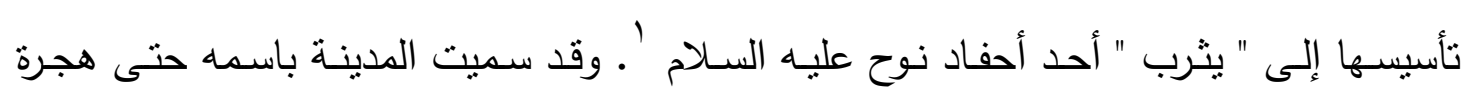

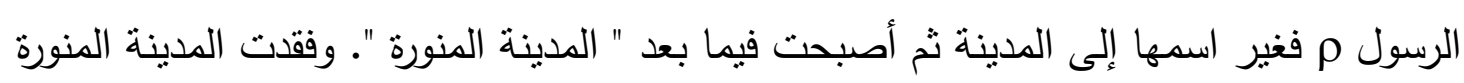

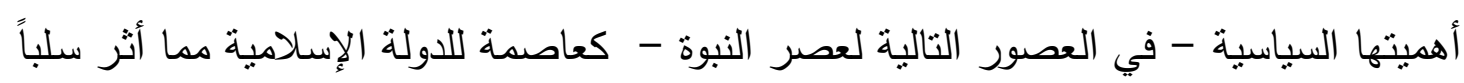
على نموها العمراني.

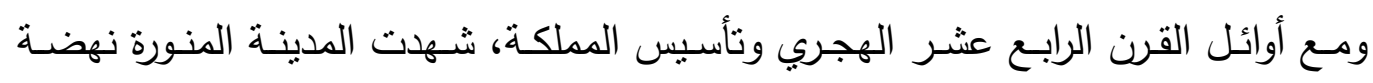
عمرانية كبيرة، بلغت أوجها في الثمانينات حيث حدثت طفرة كبيرة في كتنلتها المبنية وعدد سكانها ، كما حدث تغيير جذري في تخطيطها العمراني.

مشكثة البحث:

إن تخطيط استخدام الأرض الحضري والريفي يعتبر واحداً من أهم أولويات المخططين

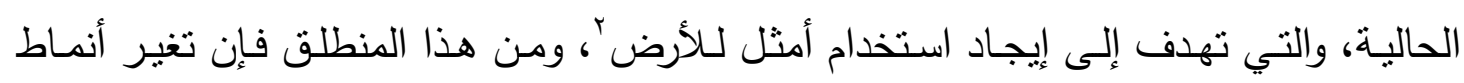

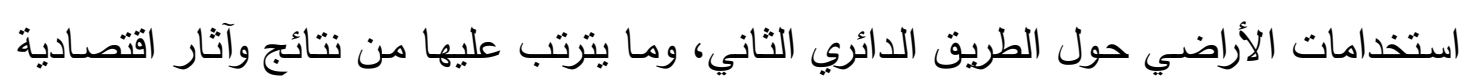
واجتماعية، كانت هي المشكلة التي أثارت رغبة الباحثين في محاولة معرفة العوامل التي تؤيثر

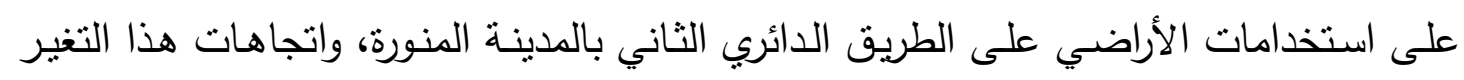
وآثاره ومدى ارتباطها بالقرارات التنظيمية المحلية.

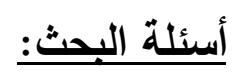
يهدف البحث إلى الإجابة عن التساؤلات الآتية:

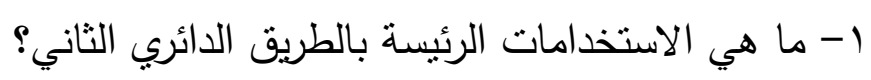

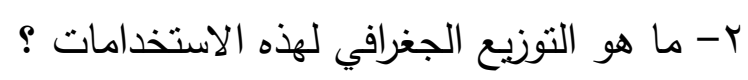

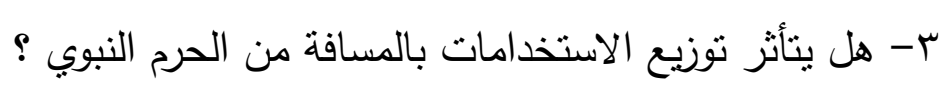

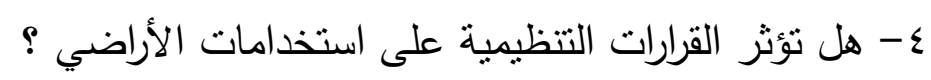

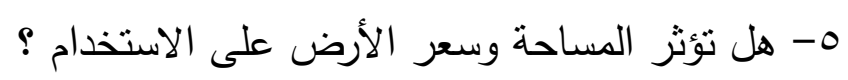

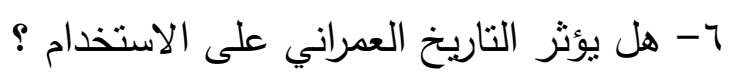




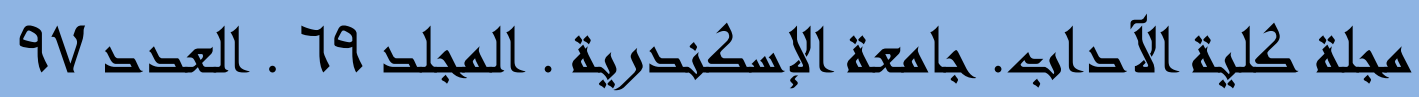

- - هل تأثز استخدام الأراضي بالطريق الدائري بخطة تطوير وتتمية المنطقة المركزية ؟ ^- ما هي إمكانيات التنمية المستقبلية للطريق؟ أهمية البحث: مLية

تشـهـ المدينـة المنورة حالياً نمـواً حضـرياُ متسـارعاً، هذا النمو الحضـري - فضـلاً عن أهميتهـا الدينيـة - بحاجـة ماسـة إلى دراسـات متعددة لتحليل نمط استخدامات الأرض الحسالي واتجاهاته بها، الذي يسـاعد بدوره في تأمين المتطلبات الخدمية والنمو العدراني المتوازن على أساس صحيح، وكذللك لتحديد المشكلات التي قد تواجه التوسع الحضري المستقبلي. كما تتمثل أهمية البحث أيضاً في محاولة وضع تصور لتخطيط وتتمية الطريق الدائري الثاني بالمدينـة المنورة بما يتتاسب مـع أهميتها وخطتها العمرانيـة واحتياجات السكان والمنـاطق العمرانية - التي يمر بها - الحالية والمستقبلية ، ومن ثم تزود الجهات ذات العلاقة في التخطيط العمراني بروئة علمية تسهم في معالجة المشاكل الناجمة عن ذلك أو تزويدها بمقترحات لتطوير كفاءة النمط الحالي. مثثل هذه الدراسات ذات أهمية كبيرة في ظل التطور العمراني الكبير الذي لترويه تشهده المملكة العربية السعودية حالياً، حيث تشلط الضوء على الجوانب الايجابية والسلبية للنمو هده العمراني الذي تشهده البلاد وفق منهج علمي. كما تأتي أهمية البحث كونه يتتاول بالدراسـة موضوعاً جديداً لمحور هام من محاور الحركة بالمدينة المنورة، ألا وهو الطريق الدائري الثاني، الذي يمثل الثريان الرئيسي للحركة بها. حيث لم تسبق دراسة مثل هذه الموضوعات الجغرافية عن المدينة المنورة من قبل. أهد|ف البحث:

$$
\text { 1 أما أهداف البحث الرئيسية فتتمثل فيما يلي: حصر وتحديد الاستخدامات بالطريق الدائري الثاني. }
$$

r- التعرف على التوزيع المكاني الحالي للاستخدامات بالطريق محل الدراسة. r- إنتاج خريطة لتوزيع الاستخدامات الحالية بالطريق الدائري الثاني بالمدينة المنورة.

الدراسات السابقة:

تعتبر مراجعة الدراسـات السابقة المدخل الطبيعي لأي دراسـة تطبيقية، حيث يتم تحديد

مدى الاستفادة من هذه الدراسات بما يخدم الدراسة الحالية. ولقد وجدت كثير من الدراسات التي

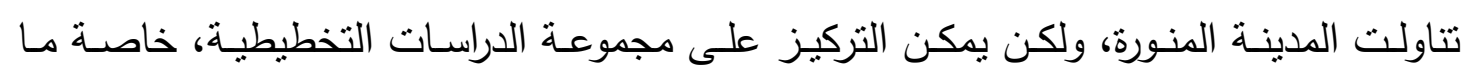
بتصل منها بتخطيط المدن وتخطيط النقل وشبكة الطرق، وكذلك الدراسات العدرانية والسكانية

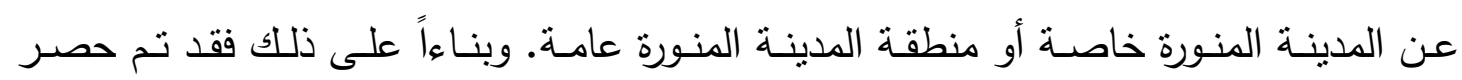
مجموعة من الدراسات منها دراستين أساسيتين تتعلقان بالنقل والمرور وهما: مشروع الدراسات الاستشارية المتكاملة للتخطيط التفصيلي الثامل للمدينة المنورة، والتي قام بها مكتب الاسنشاري 
هجلة كلية الآّايه. باهعة الإسكنحرية ـ المجلد 79 ـ العقد 9V.

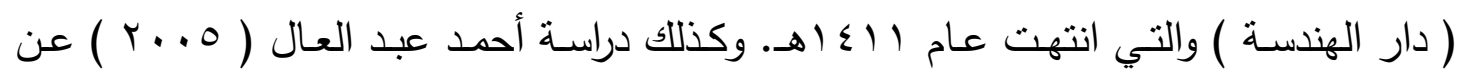

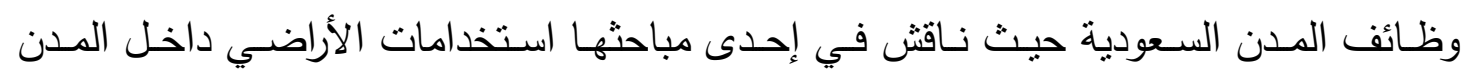
السعودية وحدد ستة من أنماط الاستخدام الرئيسة داخل المدن السعودية. كما وُجدت دراسة أخرى

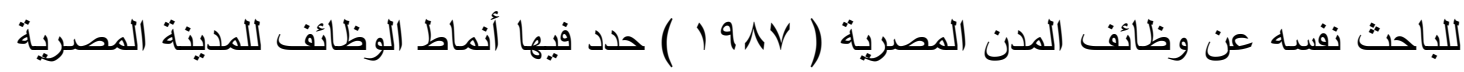

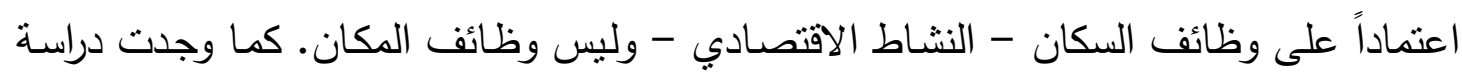

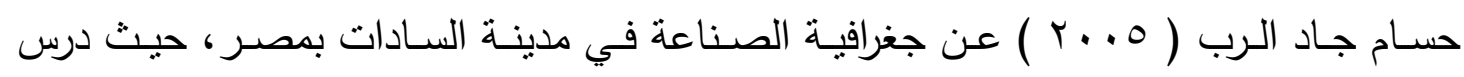
الباحث أنماط استخدامات الأراضي داخل المدينة في سياق تحليله لنشأة وتطور مدينة السادات.

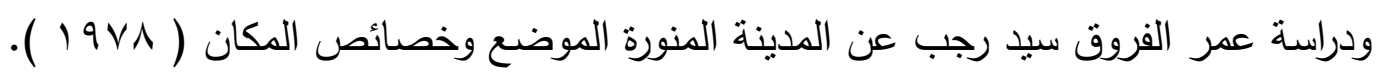

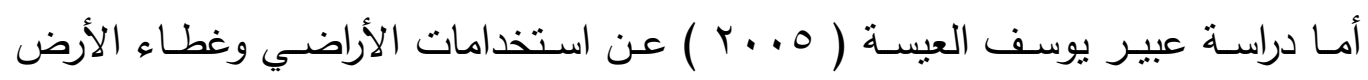
وتصنيف الأراضي حسب المناطق المناخية الزراعية وتدهور الأراضي ، فقد اعتمدت الباحثة البنة

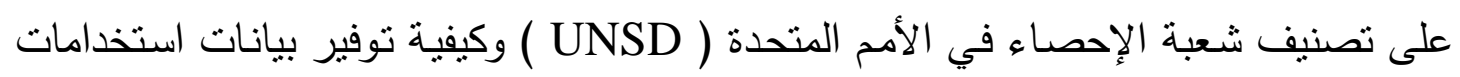

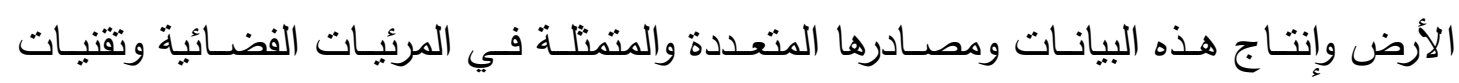

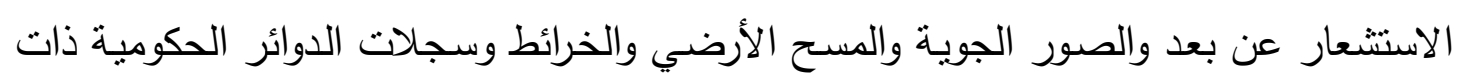
الصلة باستخدامات الأراضي.

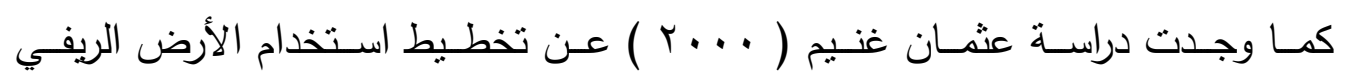

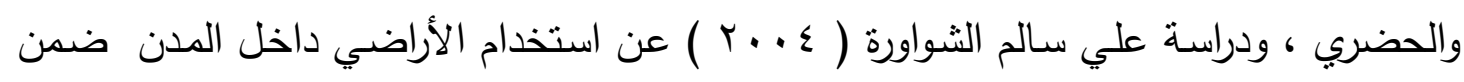

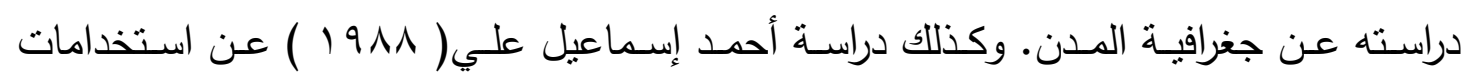
الأراضـي داخل المدن ضمن مؤلفه " دراسـات في جغرافيـة المدن" وكذلك دراسـة جمال حمدان

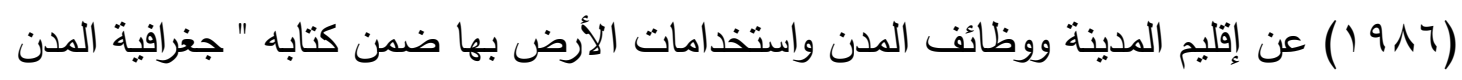
" وكذلك دراسته عن المدينة العربية (9 (9 () ضمن مطبوعات معهد الدراسات العربية بالقاهرة.

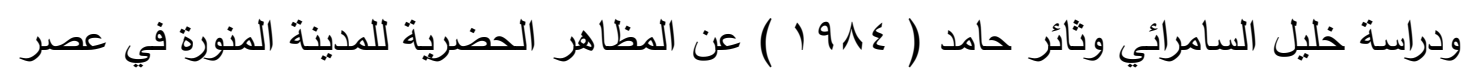
النبوة.

بالإضـافة إلى مـا سـق فقد وجـدت مجموعـة مـن الدراسـات الجغرافيـة التي توضـح

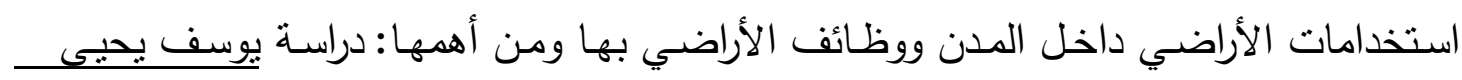

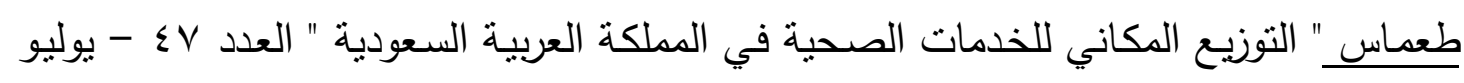

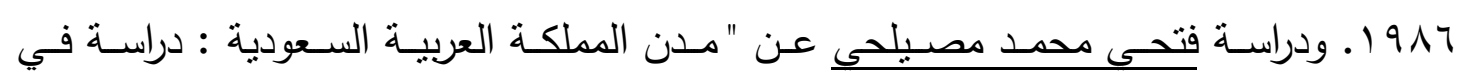

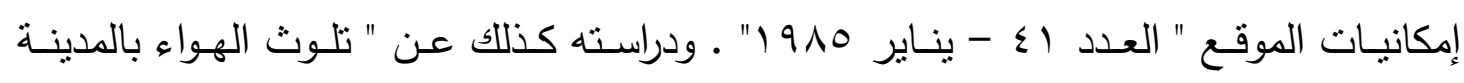

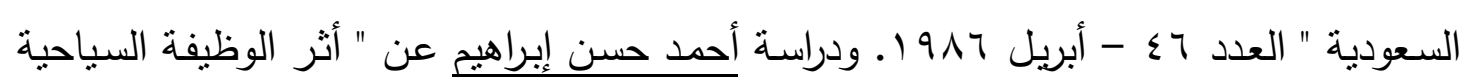

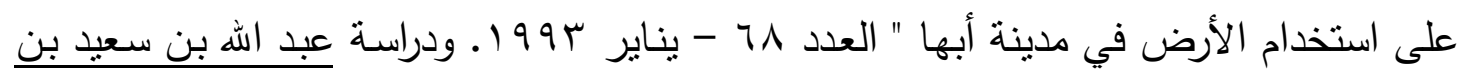

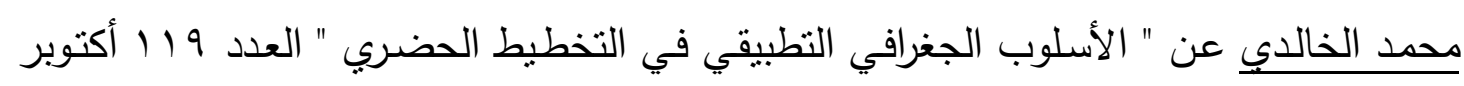




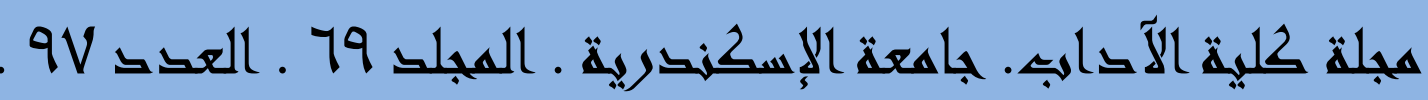

ه . . r . ودراسة فهذ بن نويصر الحريقي " المساكن والبيئة العمرانية للمدن الرئيسة في المملكة

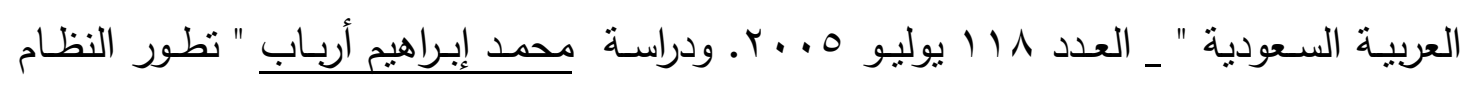
الحضـري السـودي ونموذج التركيب المكاني " العدد وq أبريـل . . . . . ودراسـة وليد عبد الله المنيس عن " التركيب الداخلي لمدينة الكويت بالمقارنـة مـع نمـاذج تراكيب المدن " العدد سل

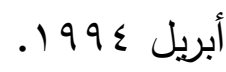

مادة الدراسة ومصادرها: تتحدد مصادر الدراسة فيما يلي أ. الكتب والمراجع والمقالات:

التي تتاقش موضوعات جغرافية المدن واستخدامات الأراضي ووظائف المدينة، وكذلك الكتب التي تعالج موضوع نظم المعلومات الجغرافية، بالإضافة إلى المصادر التاريخية للمدينة المنورة. ب. النشرات والتقارير:

التي تصدرها الهيئات والدوائر الحكومية المختلفة والتي تخدم موضوع الدراسة، على سبيل المثال أمانة المدينة المنورة ، والغرفة التجارية . ج. الخرائط: تعتبر الخربطة مصدراً رئيساً من مصادر الدراسـة الجغرافية، وتوجد عدة مقاييس لخرائط المدينة المنورة أعتمد الباحث منها على خرائط مقياس 1 : . . .0 وخرائط مقياس ا : . . . . . 1 وخرائط مقياس I : . . ه r وذلك أثناء الدراسة الميدانية عند تحديد ورفع استخدامات الأراضي بمنطقة

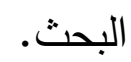

د. المرئيات الفضائية:

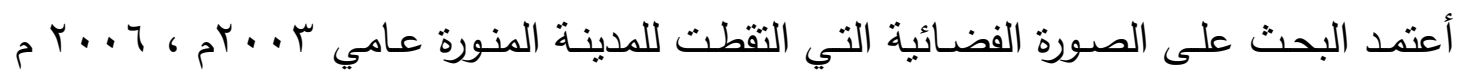

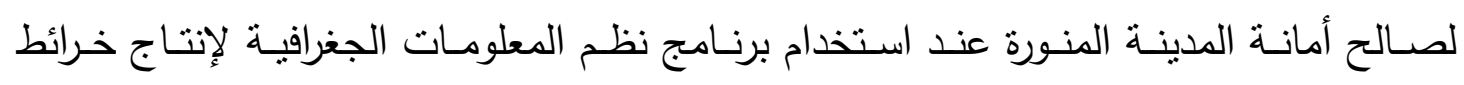
استخدامات الأراضي على الطريق الدائري الثاني.

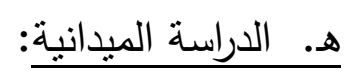
قام الباحثنان بتصميم نموذج استبيان لتحديد عدد وخصـائص قطع الأراضـي بمنطقة البحث ، وقاما بتعبئة النماذج عن طريق العمل الميداني ، وتحديد هذه القطع وترقيمها على خرائط المدينة المنورة (الطريق الدائري الثاني) مقياس I : . . . ب ثم معالجة هذه البيانات باستخدام الحاسب الآلي بطريقتين: - الآن ( ـ استخدام أحد برامج قواعد البيانات ( برنامج أكسس ، ضمن حزمة برامج ويندوز ). r. استخدام أحد برامج نظم المعلومات الجغرافية ( Map Info ). 


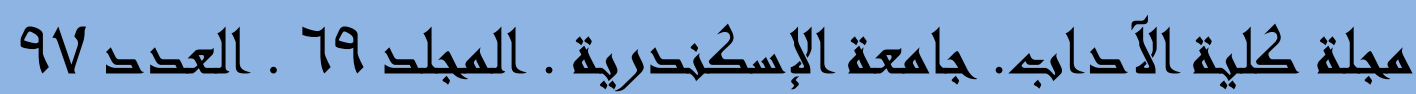

\section{منهجية الدراسة:}

تتمثل منهجيـة الدراسـة في الوسائل والأسـاليب العلمية التي يتت من خلالها تحقيق

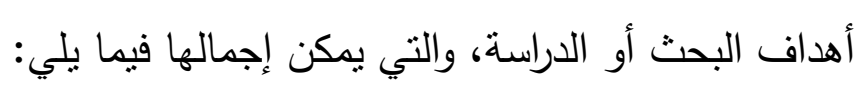

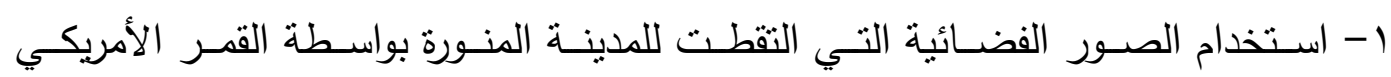

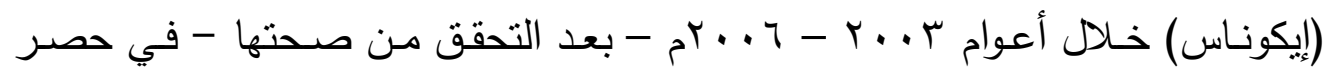

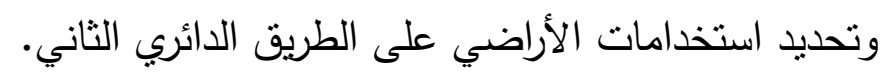

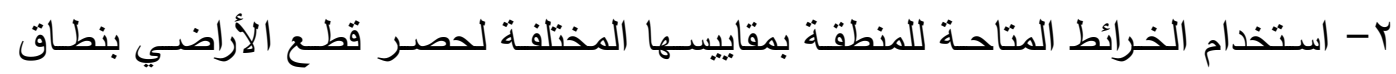

$$
\text { الطريق الدائري الثاني، وتحديدها. }
$$

r- استخدام أسلوب الاستقصاء الميداني لتحديد الاستخدامات الحالية للأراضي في منطقة الدراسة، عن طريق تصميم استبانة خاصة لذلك.

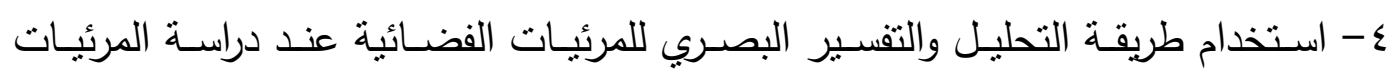

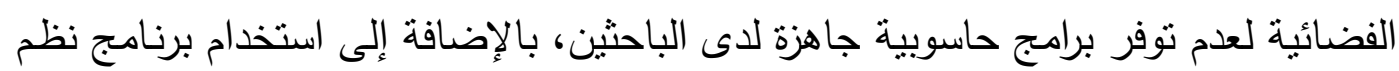

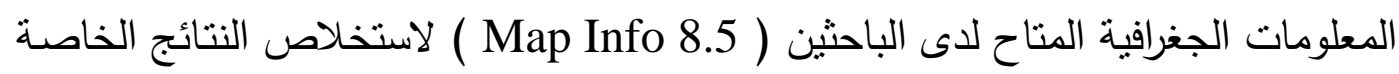
بأنماط الاستخدامات وتحديد إمكانيات النتمية، وإنتاج خرائط جديدة لمنطقة الدراسة.

خطة الدراسة:

ستبدأ الدراسة بمقدمة ومدخل، فأما المقدمة والمدخل فيتتاولا عرضاً لموضوع الدراسة

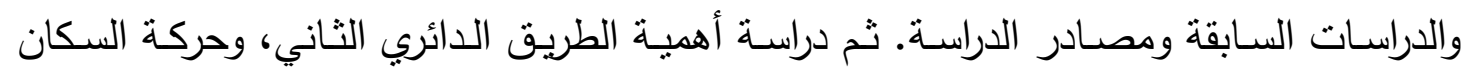

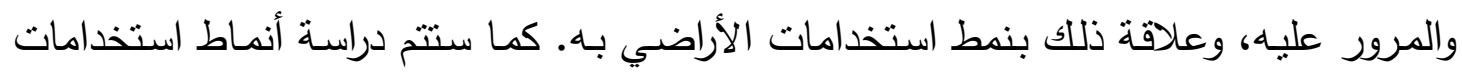

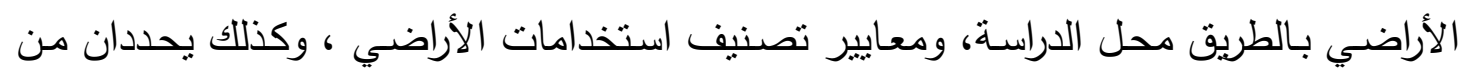

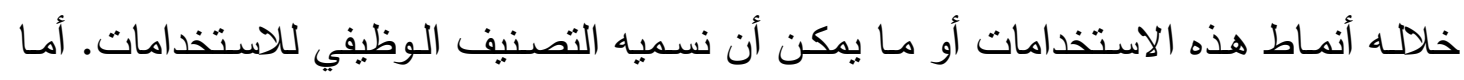
الخلاصة فتضم أهم النتائج التي توصل إليها الباحثان من خلال هذه الدان الدراسة. أولاً: خصائص الطريق الدائري الثاني: 1- أهمية الطريق الدائري الثاني وامتثاده :

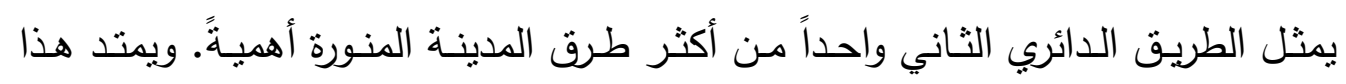

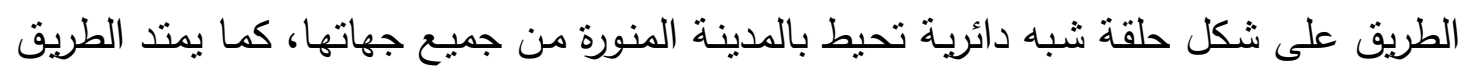
ليشمل أيضاً جميع مناطق وبلديات المدينة. ويمثل المسجد النبوي مركز الحلقة الدائرية الثانية

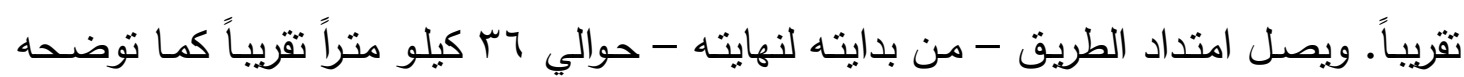

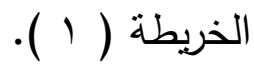




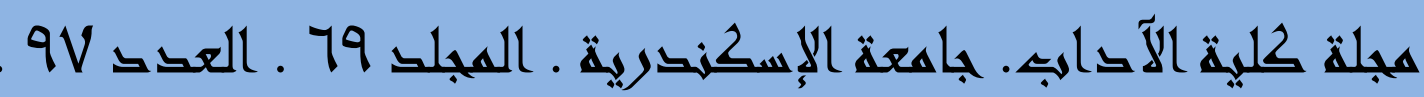

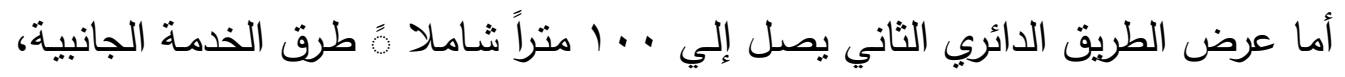

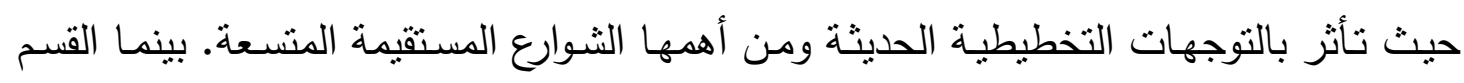

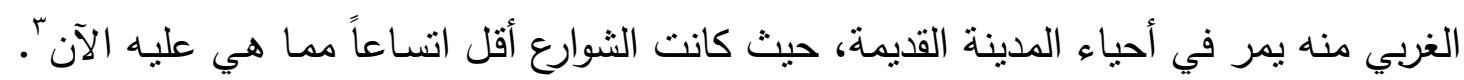

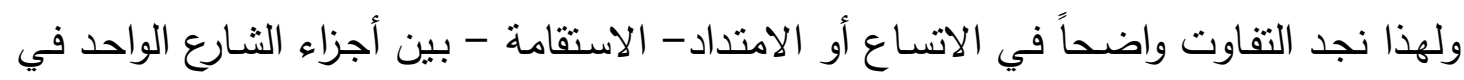

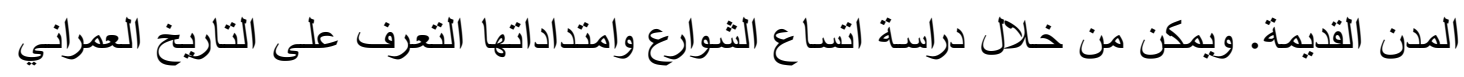

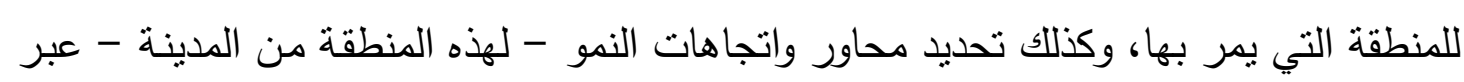
المراحل الزمنية الدختلفة.

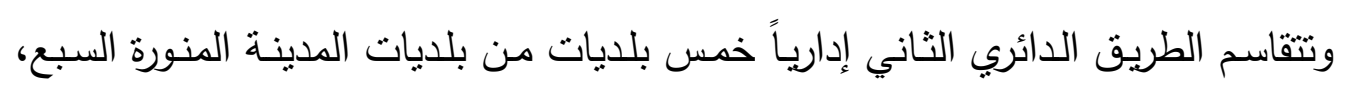

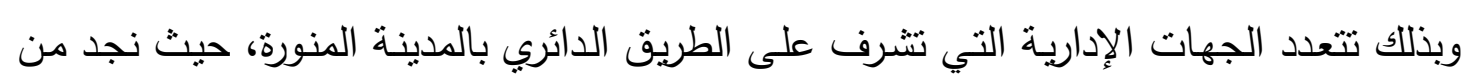

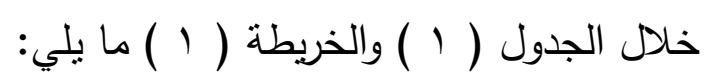

- - تضم أحياء العريض وجشم ومذينب والأصيفرين أكثر الأراضي على الطريق الدائري

$$
\text { الثاني بالترتيب كما يلاحظ من الجدول ( } 1 \text { ( ). }
$$

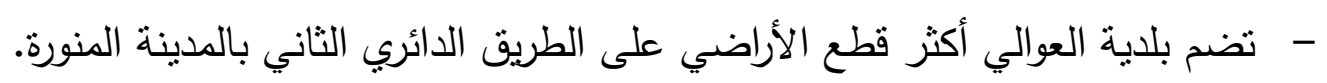

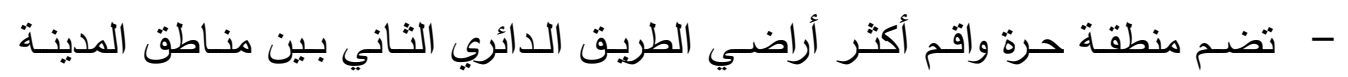

\begin{tabular}{|c|c|c|c|c|}
\hline عدد القطع & البلاية & المنطقة & الحي & م \\
\hline 01 & العقيق & الخزرج & الأصيفرين & 1 \\
\hline 01 & العقيق & سلع & الغنابس & $r$ \\
\hline$r \varepsilon$ & العقيق & بني سلمة & القبلتين & $r$ \\
\hline ro & العقيق & العقيق & الويرة & $\varepsilon$ \\
\hline 11 & العقيق & العقيق & عروة & 0 \\
\hline$\varepsilon$. & العوالي & اللابة & الخالدية & 7 \\
\hline$v$. & العوالي & حرة واقم & العريض & $v$ \\
\hline rq & العوالي & قناة & المبعوث & $\wedge$ \\
\hline rI & العوالي & قناة & شظاة & 9 \\
\hline Tr & العوالي & ميطان & جشم & 1. \\
\hline 89 & العوالي & ميطان & مذينب & 11 \\
\hline Or & العوالي & بطدان & مهزوز & Ir \\
\hline
\end{tabular}

المحيطة بالطريق.

r ـ عمر الفاروق سيد رجب: المدينة المنورة الموضع وخصائص المكان، مجلة البحوث و الدراسات العربية،

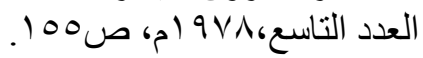




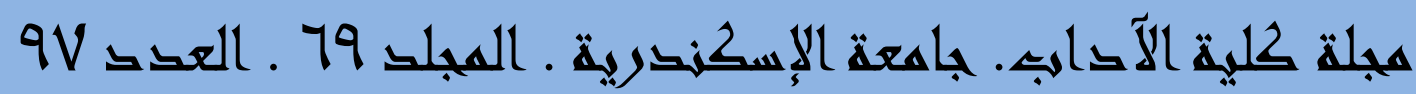

\begin{tabular}{|c|c|c|c|c|}
\hline Yq & العيون & الغندق & الراية & Ir \\
\hline 10 & العيون & الخندق & الفتح & $1 \leq$ \\
\hline 19 & العيون & الجرف & العيون & 10 \\
\hline 1. & العيون & الجرف & بئر عثمان & 17 \\
\hline$\wedge$ & أحد & أحد & جبل أحد & iv \\
\hline$r$ & أحد & أحد & التلعة & 11 \\
\hline$r r$ & أحد & أحد & الشهاء & 19 \\
\hline 11 & أحد & المستراح & الارع & $r$. \\
\hline rr & أحد & الأوس & بني حارثة & ri \\
\hline$r \Lambda$ & قباء & المناهل & الروابي & rr \\
\hline v & قباء & المناهل & السد & $r r$ \\
\hline$\varepsilon$. & قباء & قباء & الظاهرة & $r \varepsilon$ \\
\hline 10 & قباء & قباء & العصبة & ro \\
\hline rq & قباء & قربان & العهن & YT \\
\hline ir & قباء & الهجرة & القصواء & $r v$ \\
\hline r & قباء & الهجرة & الحديقة & $r \wedge$ \\
\hline ro & قباء & الهجرة & الخاتم & rq \\
\hline$\wedge \wedge \mathrm{r}$ & 0 & 11 & rq & الإجمالي \\
\hline
\end{tabular}

r - الحركة المرورية بالطريق الائري الثاني:

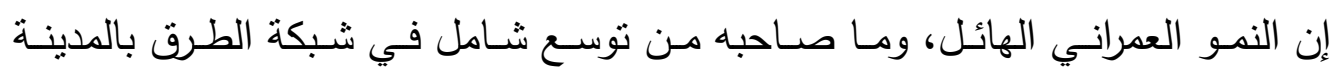

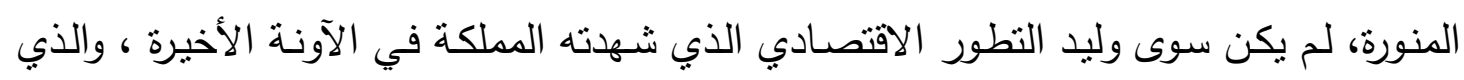

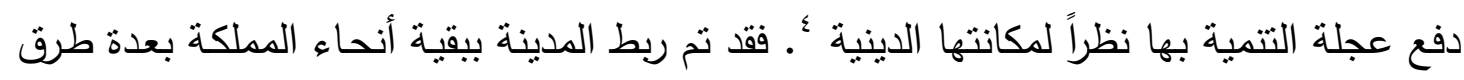

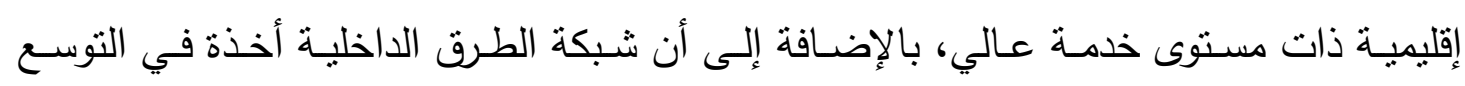

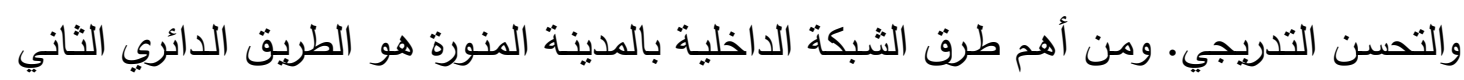
الذي يربط بين جميع محاور الحركة الرئيسية بها. وتعتبر شبكة الطرق الداخلية بالمدينة المنورة إنثعاعية النمط ( التكوين ) لخدمة حركة لهنة المرور المرتبطة بالمسجد النبوي الثريف. وقد ظلت شبكة الطرق الداخلية دون تغيير لفترة زمنية

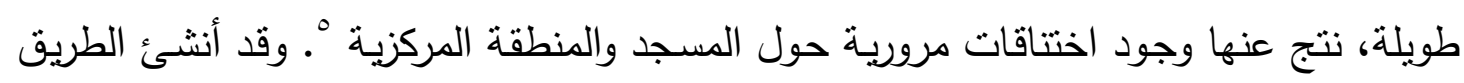

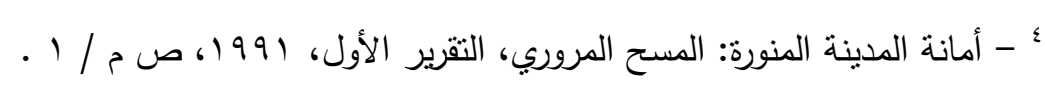

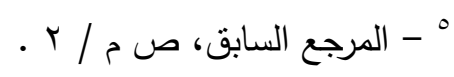




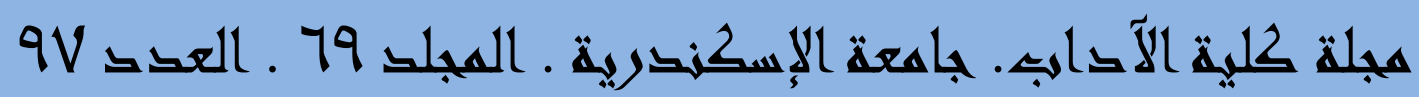

الدائري الأول ثم الطريق الدائري الثاني لعلاج هذا الوضع ولتحقيق نوع من الانسيابية في حركة

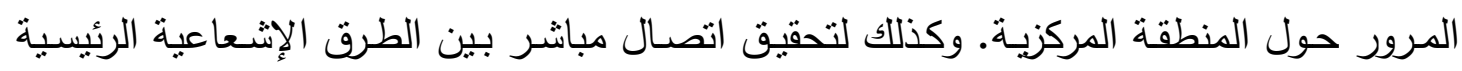
بالمدينة المنورة والطرق الدائرية وكذلك بيقية أجزاء ومناطق المدينة.

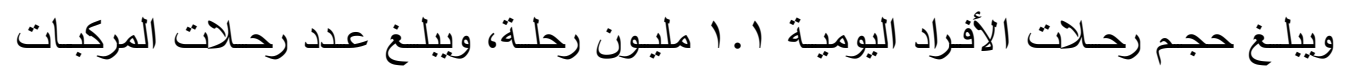

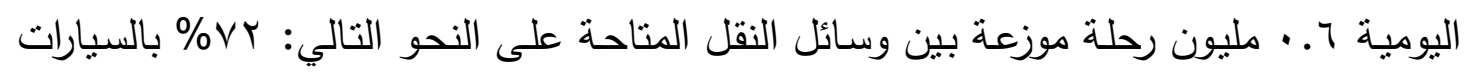

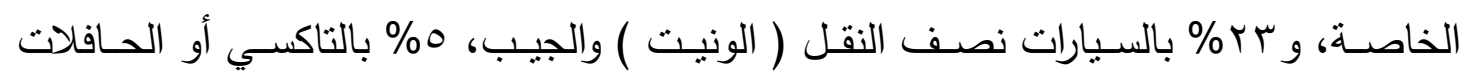

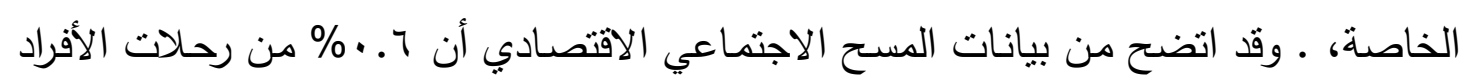

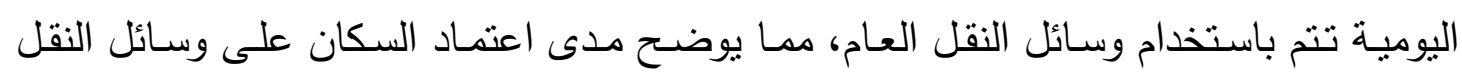
الخاصة للقيام برحلاتهم اليومية.

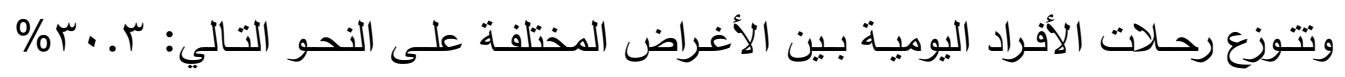

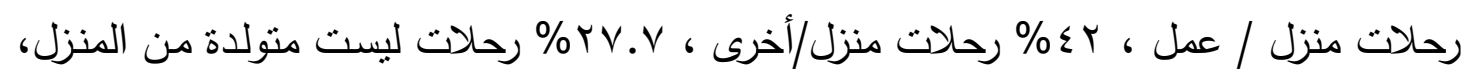

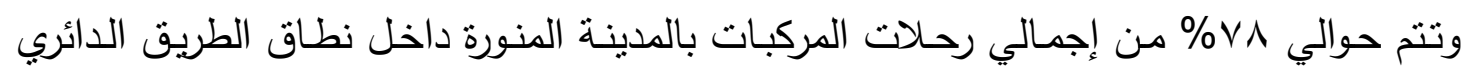

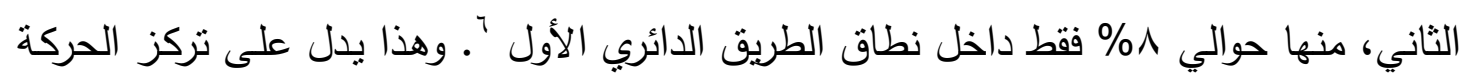

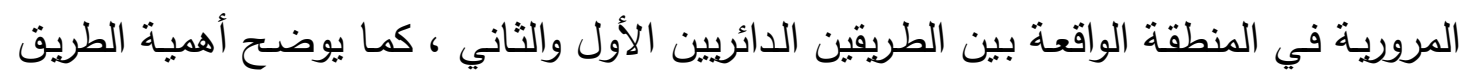

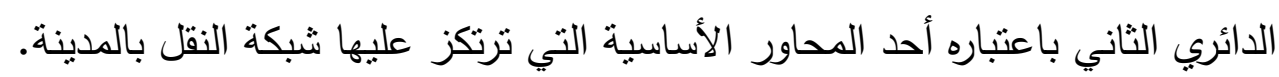

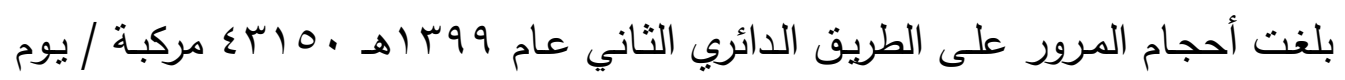

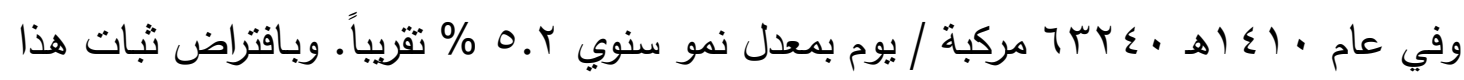

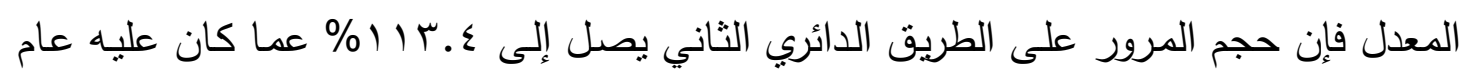

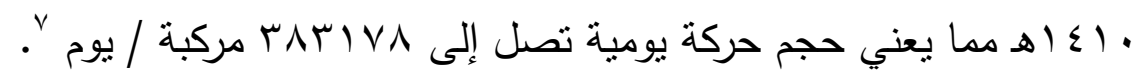

\section{r- علاقة الطريق الدائري الثاني بثبكة الطرق بالمدينة المنورة}

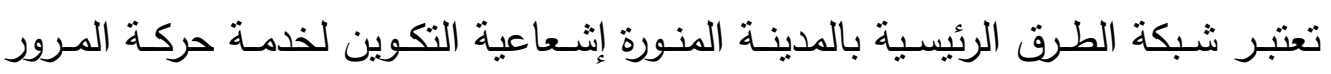
المرتبطة بالمسجد النبوي الشريف. وقد ظلت شبكة الطرق دون تغيير لفترات زمنية طويلة، نتج

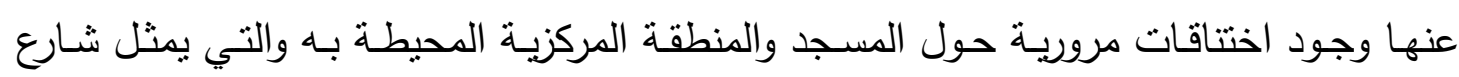
سلطانة جزء منها. وقد أنثئ الطريق الدائري الأول لتحقيق نوع من الانسيابية في حركة المرور

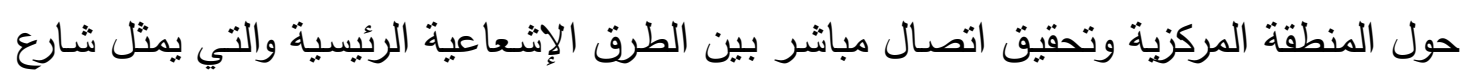
سلطانة واحداً منها بل أهمها على الإطلاق. 


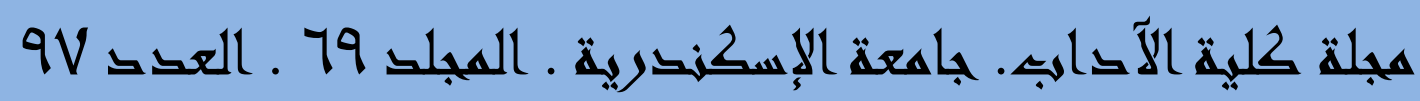

أما شبكة الطرق الثانوية والمحلية بالمدينة المنورة فهي عثوائية وضيقة - بصفة عامـة - في الجزء القديم من المدينة، كما تفتقر هذه الثبكة إلى وجود تدرج وظيفي واضح يخدم أحجام واتجاهات حركة المرور داخل الكتلة السكنية الحالية. كما أنها تفتقر أيضاً إلى تخطيط هندسي يسمح بسـهولة حركة السيارات والمشـاة. مما نتج عنه ميل قائدي المركبات إلى استخدام شبكة الطرق الرئيسية في معظم رحلاتهم مما زاد العبء على هذه الثبكة، بالإضـافة إلى عدم وجود وسيلة ربط مباشرة بين الأحياء المتجاورة.

ويلتقي الطربق الدائري الثاني مـع مجموعة من الثـوارع أو الطرق الهامـة والرئيسـة في

شـبكة الطـرق بالمدينة المنورة، منها طريـق أبو بكر الصديق المعروف بثـارع سـلطانة. حيث ميث

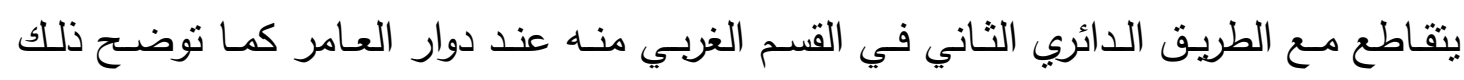
الخريطة ( r ) ). وتمثن نقطة الالتقاء هذه إحدى نقاط القطع الرئيسة في شبكة الطرق بالمدينة المنورة، كما تعتبر واحدة من النقاط التي تعترض سيولة حركة المواصلات بالمدينة المنورة. كما يلتقي الطريق الدائري الثاني مع طريق تبوك / المدينة المنورة ، الذي يمثل محوراً هاماً من محاور الحركة في المدينة المنورة عند دوار القبلتين. أما في القسم الجنوبي الثرقي من الطريـق الدائري الثاني فيتفرع منـه أو يلتقي بـه مجموعة من الثـوارع الثانويـة في شبكة طرق المدينة، منها شـارع الإمـام مالك الذي يربط بين الطربق الدائري الثاني وشـارع سلطانة، وكذلك شـارع حي ( حارة ) النصر الرئيسي. بالإضـافة إلى عدد من الثـوارع التي تلتقي بالثـارع من الإن جانبيه و تمثل جزءاً من شبكة الطرق بالمدينة المنورة كما نوضحه الخريطة ( r ). بالإضـافة إلى مجموعة من الطرق والشوارع الهامـة الأخرى مثنل طريق المطار وطريق الجامعات وطريق الملك عبد العزيز وطريق الملك فهد وطريق الملك عبد الله وشارع الأمير عبد المحسن وشارع علي بن أبي طالب وشارع الأمير سلطان.

\section{ثانباً: أنماط استخدامات الأراضي بالطريق الدائري الثاني:}

يمثل نمط استخدام الأرض في أية مدينة نتاجاً للتطور الذي مرت به المدينة خلال فترة طويلة من تاريخها العدراني، واستخدامات الأراضـي في أيـة مدينة أكثر من مجرد كونـه صورة

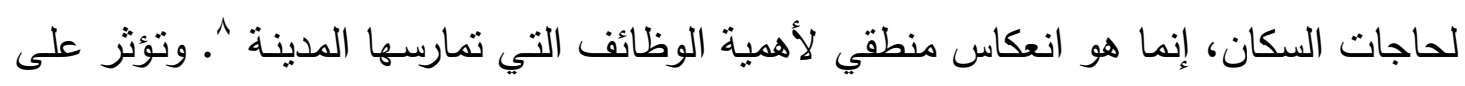
المدينة المنورة وظيفتها الدينية ولكنها ليست كما ذكر الكثيرون أسيرة هذه الوظيفة، فالمدن الدينية 


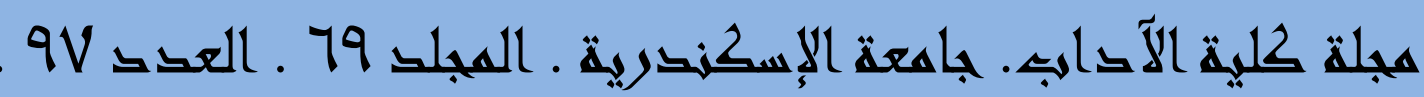

صـغيرة الحجم بصـفة عامـة، وهي مدن مؤقتة. ويختلف الحسال هنـا مـع المدينـة المنـورة ومكـة

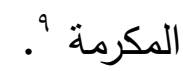

وتتعـد أنمـاط اسـتخدامات الأراضـي بـالطريق الدائري الثاني ، وقد أعتمـد الباحث عند دراسـة الاستخدامات على ما يلي: 1- استخدام الدور الأرضي. r- - استخدام المبني كاملاً. ويمكن دراسة هذا الموضوع من خلالم ما يلي: أولاً: معابير تصنيف الاستخدامات. ثانياً: التصنيف الوظيفي للاستخدامات. وقد حدد الباحث مجموعة من المعايير التي يتم على أساسها تصنيف استخدام الأرض بمنطقة الدراسة، هي كما يلي: الئ ( ـ معيار الوظيفة ( الاستخدام ). وسوف يتم دراسة الوظيفة أو الاستخدام من خلال ما يلي: أ. ألاستخدام التجاري. ب. الاستخدام السكني. ج. الاستخدام السكني/ التجاري. د. الاستخدام الخدمي. هـ. الاستخدام الصحي. و. الاستخدام التعليمي.

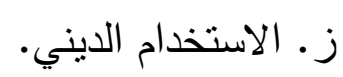
ح. الاستخدام الإداري ( الحكومي ).

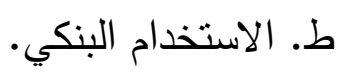
ك. استخدامات أخرى. Y. كعيار طبيعة الإشغال: وسوف يتم دراسة طبيعة الإشغال من خلال ما يلي: أ- أراضي أحادية الإشغال. ب- أراضي ثنائية الإشغال. ج- أراضي متعددة الإشغال. 


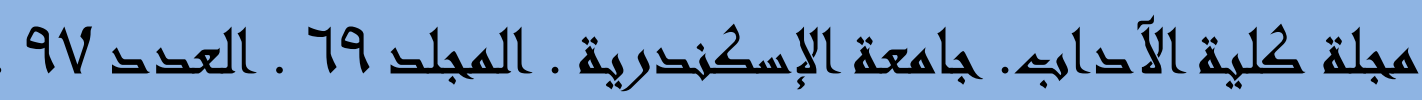

r. معيار حالة الاستغلال:

وسوف يتم دراسة حالة الاستغلال من خلال ما يلي:

أ- أراضي مستغلة.

ب - أراضي غير مستغلة.

ع. معيار المساحة ( الحجم )؛

وسوف يتم دراسة المساحة من خلال ما يلي:

أ- أراضي مساحتها أقل من . . . مثر مربع.

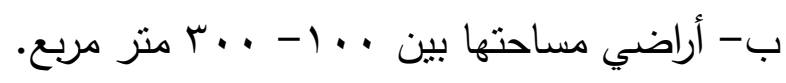

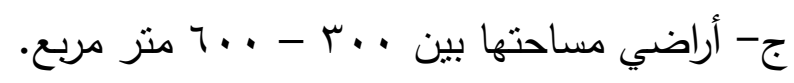

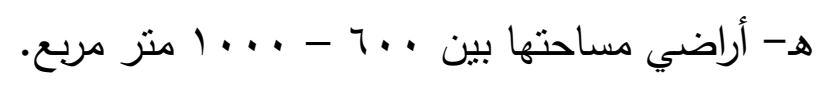

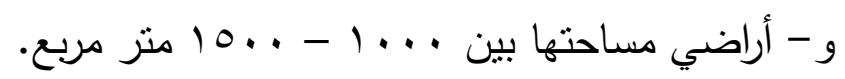

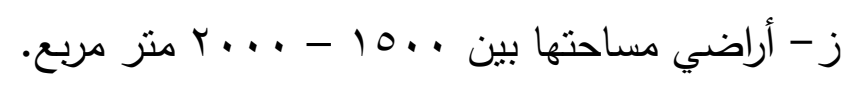

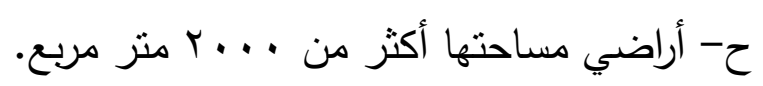
ه. معيار الارتفاع ( عدد الطوابق ).

وسوف يتم دراسة هذا المعبار من خلال تصنيف الأراضي إلى الى إنى أ- أراضي ذات طابق واحد.

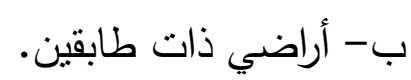

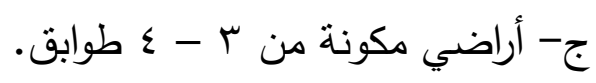

د - أراضي مكونة من 0 طوابق فأكثر .

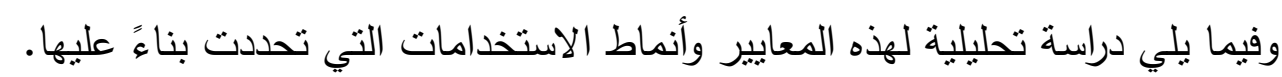

1.المعيار الوظيفي:

تم حصر عدد AN قطعة أرض على كلا جانبي الطريق الدائري الثاني ، تختلف فيما

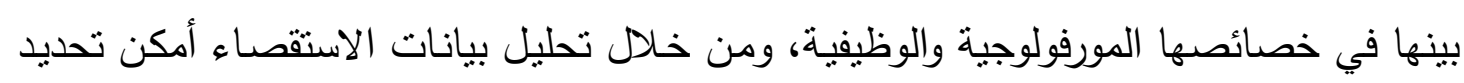
وظيفة واستخدام كل قطعة أرض بالطريق فكانت كما يلي:

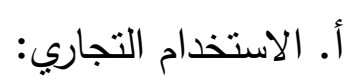

بلغت أعداد قطع الأراضي ذات الاستخدام التجاري بالطريق الدائري الثاني ع V قطعة

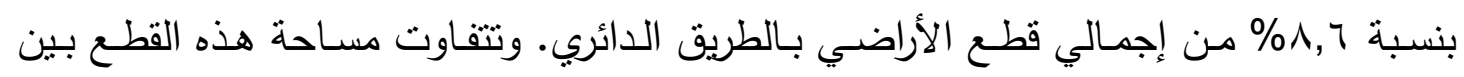

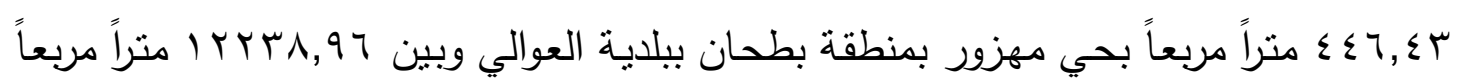

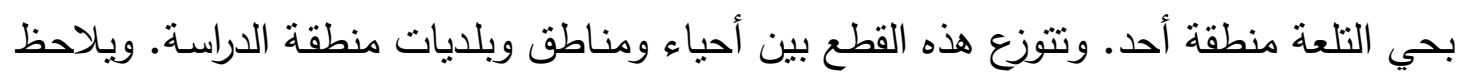

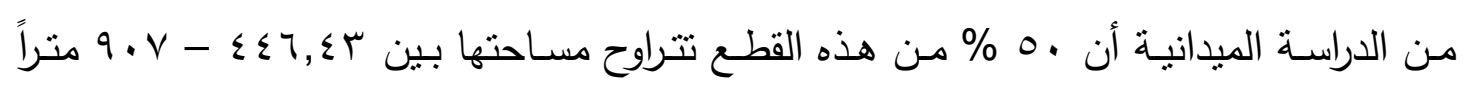




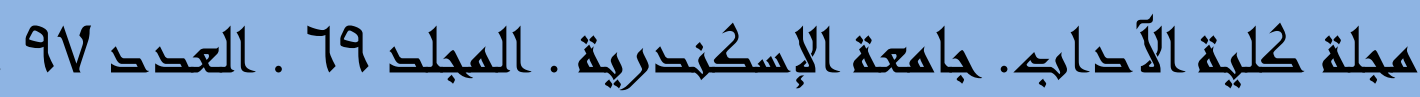

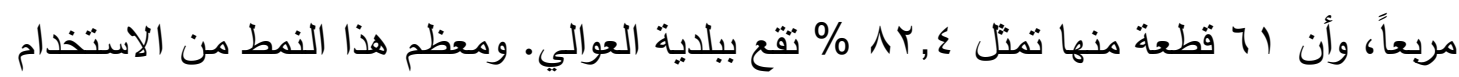
التجاري يتركز في أنشطة محددة وهي المعارض التجاريـة سواء للأجهزة الكهربائية المنزلية أو أو الونهية المطابخ أو معارض السيارات.

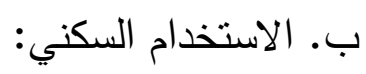

تصل أعداد قطع الأراضـي المخصصـة للاستخدام السكني على الطريق الدائري الثاني

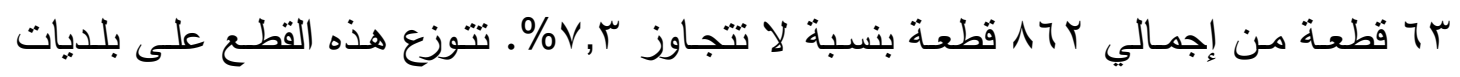

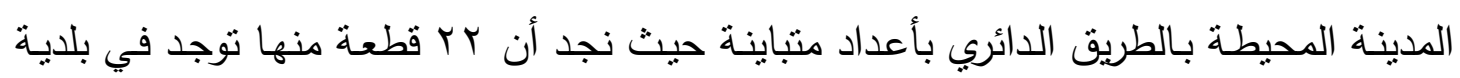
قباء تمنت هr \% من إجمالي قطع الأراضي السكنية بالطريق الدائري الثاني. وان V V قطعة تقع

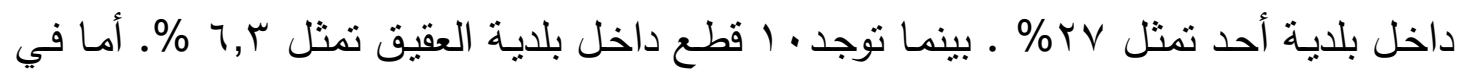

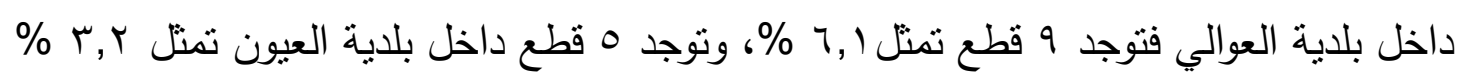
من إجمالي قطع الأراضي السكنية بالطريق الدائري الثاني • ج. الاستخدام السكني/التجاري: يعتبر الاسـتخدام السكني التجـاري واحداً مـن الاسـتخدامات الرئيسية للأراضـي داخل المدينة المنورة عامـة وداخل الطريق الدائري الثاني بصفة خاصة، حيث يضم بم قطعة أرض الثر تشكل • 1 \% تقريباً من إجمالي أعداد الأراضي به. ويتوزع هذا النمط من الاستخدام على أحياء وبلديات المدينة المنورة المحيطة بالطريق بأعداد غير متساوية، كما تختلف هذه الأراضي أيضاً

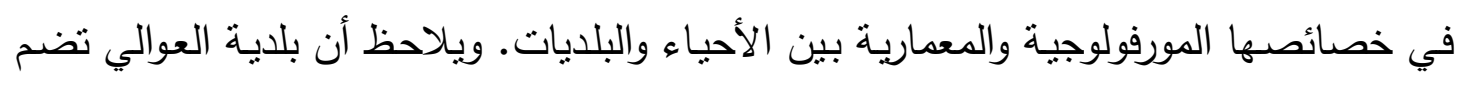

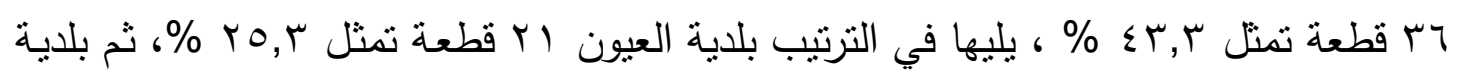
العقيق التي تضم V V قطعة بنسبة تصل إلى ع, . r \% ب بينما تأتي بلديتا قباء وأحد منتأخرتين حيث تضم ه قطع و ع قطع بالترتيب. أما التوزبع على مستوى الأحياء فنجد أن حي العربض

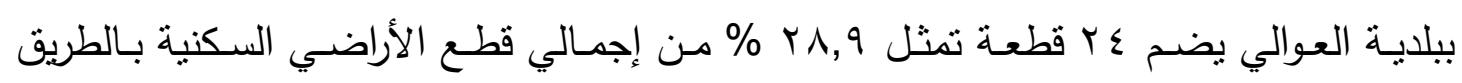

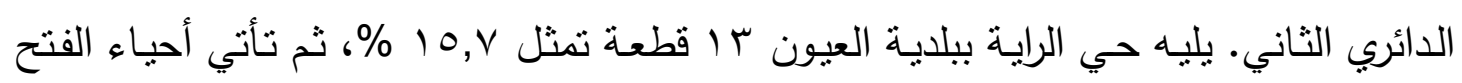
والعنابس بكل منهما V قطع، أما حي الخالدية وحي الأصيفرين فيضم كل منهما ه قطع. أما بقيـة الأحياء على الطريـق الدائري فتضم بين ع قطع إلى قطعة واحدة كمـا يتضـح ذلك من وحن

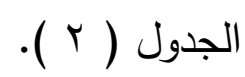

\begin{tabular}{|c|c|c|c|c|c|c|}
\hline الإجمالي & العيون & العقيق & قباء & أحد & العوالي & البلدية \\
\hline & rI & IV & 0 & $\varepsilon$ & די & العدد \\
\hline
\end{tabular}




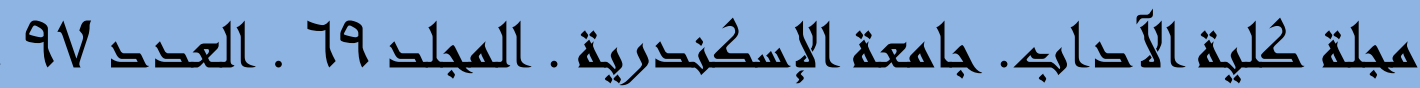

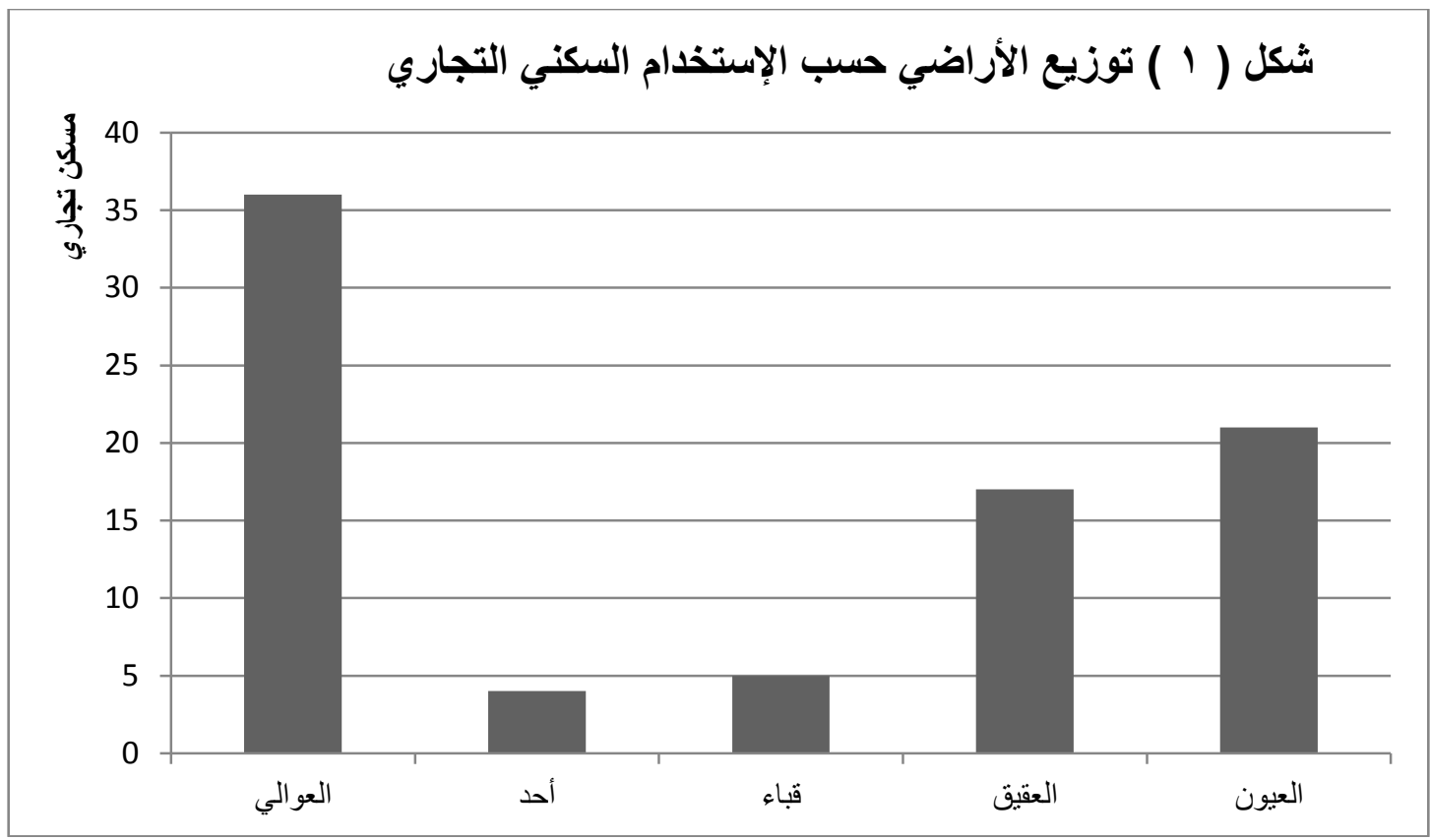

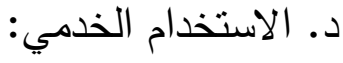

تمثنل الخدمات بأنواعها المختلفـة ومستوياتها المتعددة واحدة مـن الوظـائف الأساسـية للمدن. ولذا فإن الاستخدام الخدمي بمستوياته وأثنكاله يحتل مساحات كبيرة من الاستخدامات على الطريق الدائري الثاني بالمدينة المنورة، سواء كان الاستخدام الخدمي منفرداً أو مشتركاً مع أنشطة واستخدامات أخرى في المبنى ذاته. وتصـل أعداد الأراضـي التـي يشـلها الاسـتخدام الخدمي منفرداً ه قطعـة تمثنل 9, r \% من إجمالي قطع الأراضـي السكنية بـالطريق الدائري الثاني. أمـا بالنسبة لمختلف الاستخدامات فتصل أعداد القطع التي تمارس بها وظيفة خدميـة

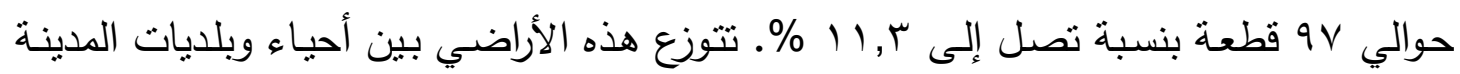
المنورة المطلة على الطريق الدائري الثاني بأعداد ونسب متباينة، حيث نجد أن بلديـة العقيق

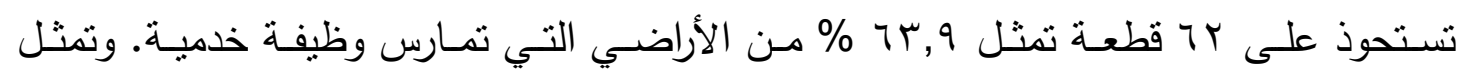
الخدمات الثخصية أهم الخدمات التي تقدم على الطريق الدائري الثاني في بلدية العقيق خاصـة بأحياء العنابس والأصيفرين اللذان يمثنلان أقرب الأحيـاء إلى الكتلـة السكنية القديمـة بالمدينـة المنورة. هـ. الاستخدام الصحي: يمثل هذا الاستخدام المستشفيات والمراكز الصـحية بأنماطها المختلفـة بالإضـافة إلى الصيدليات، ويلاحظ أن هذا النمط من الاستخدام محدود على الطريق الدائري الثاني على الرغم من وجود عدد من الصيدليات التي افتتحت بالطريق الدائري الثاني حديثاً. حيث نجد أن أعداد هذا النمط تصل فقط إلى سا قطعة بنسبة تصل 0, 1 \% من إجمالي قطع الأراضي السكنية 


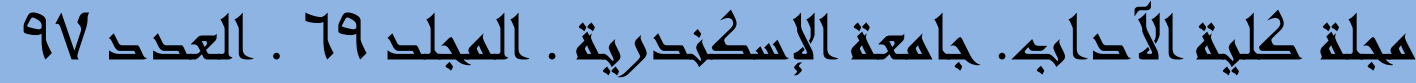

بـالطريق الدائري الثاني. ومـن ثم فإن أعداد المستثفيات والمراكز الصحية على الطريق لا

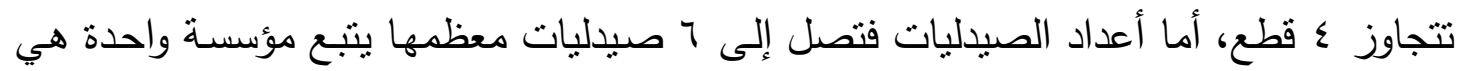

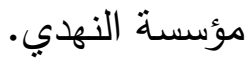

$$
\text { و. الأراضي الفضاء: }
$$

يعتبر هذا الاستخدام أكثر الاستخدامات انتشـاراً على الطريق الدائري الثناني بالمدينة

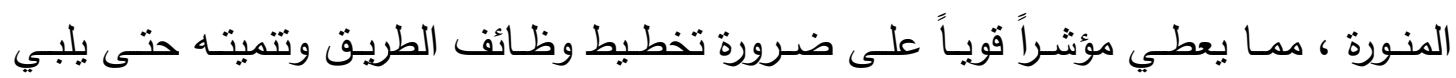

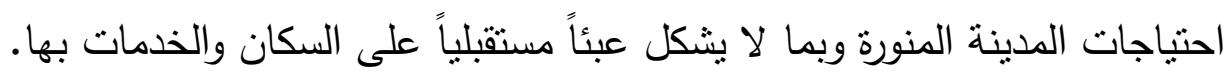
جدول ( r ) توزيع الأراضي الفضاء حسب المساحة بالمتز المربع

\begin{tabular}{|c|c|c|c|c|c|c|c|}
\hline الإجمالي & أكثر من & $r \cdots-1 \ldots$. & $1 \ldots \ldots-0 \ldots$ & $0 \ldots-1 \ldots$ & $1 \ldots-0 \ldots$ & أقل من & السساحة \\
\hline r & 11 & rq & 19 & 9v & $10 \mathrm{~V}$ & «1 & العدد \\
\hline
\end{tabular}

وتصل أعداد الأراضي الفضاء القابلة للتتمية على الطريق الدائري rVA قطعة متباينة

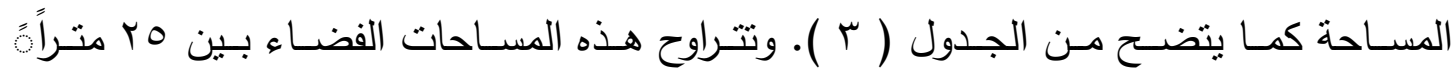
و الم المناً مربعاً.

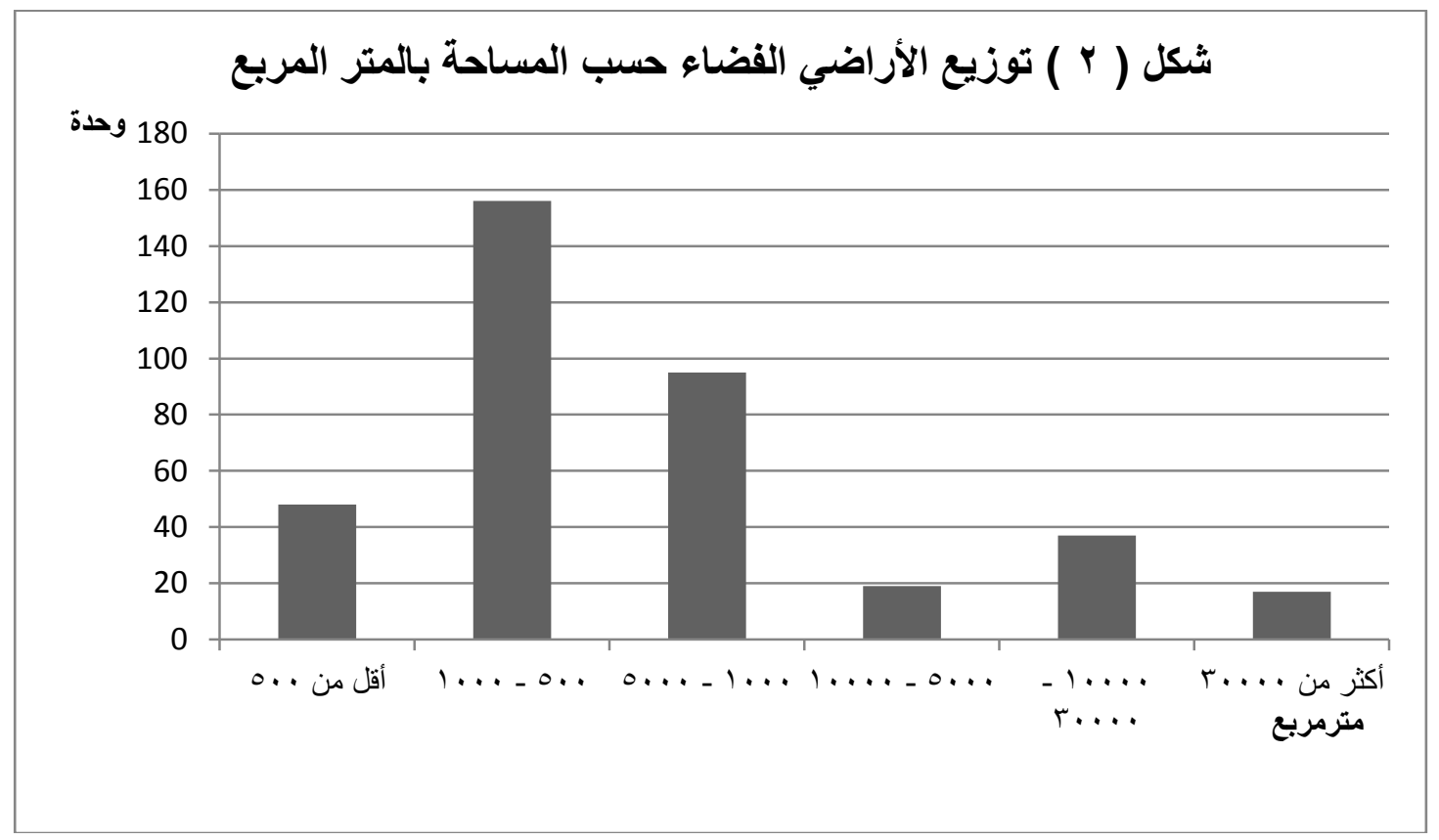

ز. الأراضي تحت الإنشاء: 


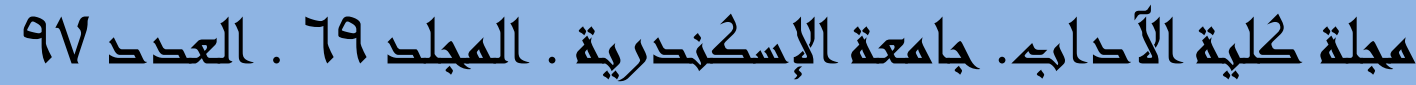

تصل أعداد الأراضي في هذا النمط من الاستخدام إلى اء قطعة، تتوزع بين أحياء

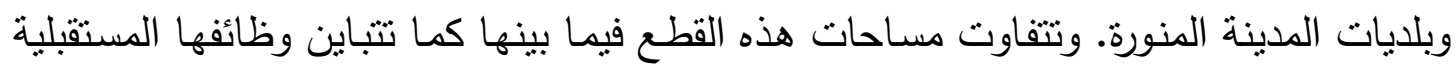
أو المنثأة من أجلها. جدول ( ؛ ) توزيع الأراضي تحت الإنشاء حسب المساحة بالمتز المربع

\begin{tabular}{|c|c|c|c|c|c|c|}
\hline الإجمالي & $\begin{array}{l}\text { أ. Oثر من } \\
\end{array}$ & ro.. & r... & $1 \ldots$ & أ. ـ م من & المساحة \\
\hline$\{1$ & - & V & $r_{1}$ & 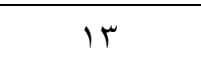 & - & العدد \\
\hline
\end{tabular}

ويلاحظ أن التوزيع الجغرافي للأراضي تحت الإنشـاء يتركز بصفة أساسبة في بلدية العوالي، وفي ثلاثة فقط من أحيائها هم حي مذينب وحي مهزوز وحي جشم ، حيث يضم كل

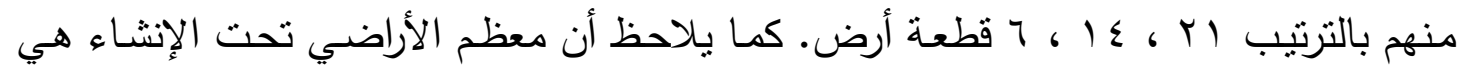

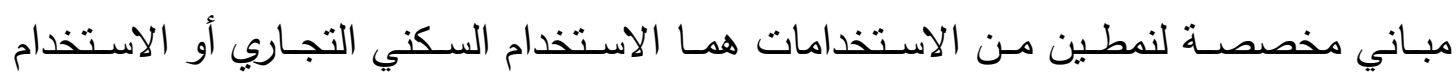
التجاري.

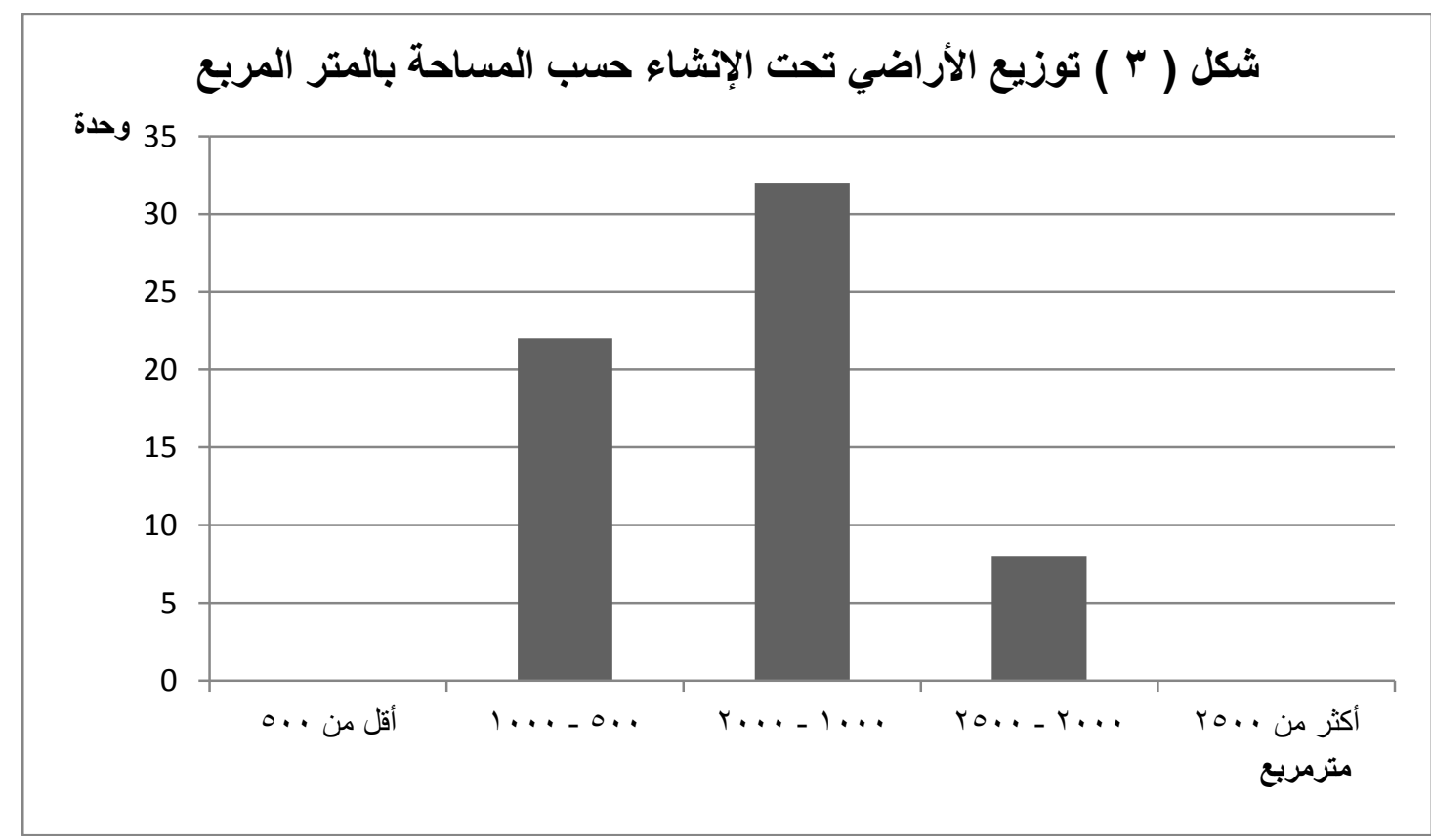

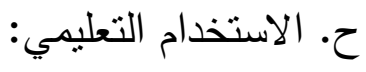

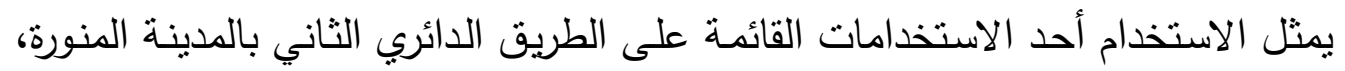

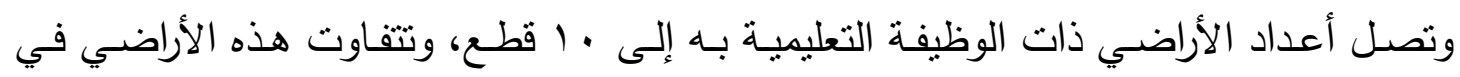

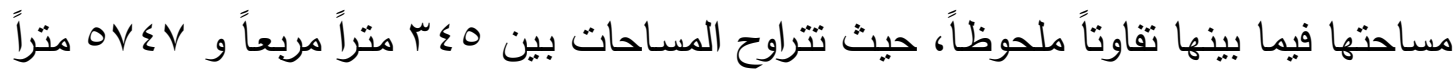

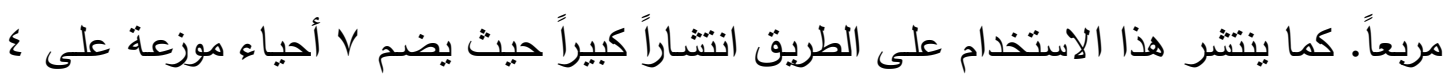


هجلة كلية الآّايه. باهعة الإسكنحرية ـ المجلد 79 ـ العقد 9V.

بلديات من البلديات الخمس المحيطة بالطريث الدائري الثاني. ويتوزع هذا الاستخدام على أحياء المدينة المنورة المطلة على الطريق، حيث يضم حي جشم ببلدية قباء ب مدارس، بينما يضم كل من حي الثهداء ببلديـة أحد وحي القبلتين ببلديـة العقيق مدرستين، أمـا أحياء العصبة والخاتم والتلعة فيضم كل منهم مدرسة واحدة فقط. أما على مستوى البلديات فنجد أن التوزيع ياخذ شكلاً حيث تضم كل من بلدية قباء والعقيق مدرستين، أما بلديتا أحد والعوالي فتضم ثلاثة مدارس بكل منهما. ومعظم المدارس التي تقع على الطريـق الدائري هي مدارس حكوميـة باستثناء مدرسـة أهلية واحدة فقط.

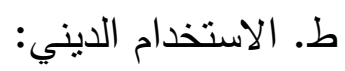

يضم هذا النمط من الاستخدام 9 قطع من الأراضي تتوزع على الطريق الدائري الثاني، وتتفاوت في مساحتها وتصميمها المعماري ومساحاتها بين بلديات وأحياء المدينة المنورة تفاوتاً

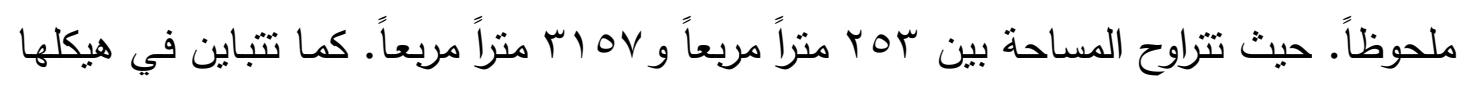

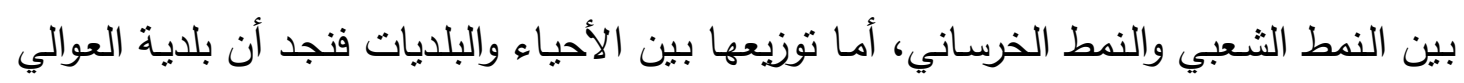
تضم ثنلثة مساجد، بينما تضم بلديتا أحد وقباء مسجدين بكل منهما، أما بلديتا العقيق والعيون

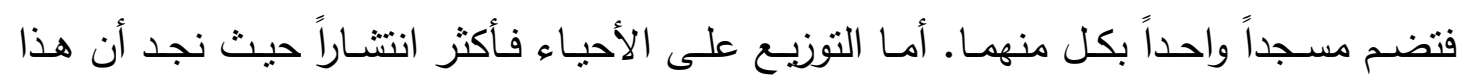
الاسـتخدام يتوزع على 7 أحيـاء، حيـث يضـم كل مـن أحيـاء العـريض وبنـي حارثـة والظـاهرة مسجدين ، أما أحياء الفتح والأصيفرين ومهزوز فيوجد مسجداً واحدا بكل منها.

$$
\text { ي. الاستخدام الإداري والأمني ( الحكومي ): }
$$

تصـل أعداد الأراضي في هذا النمط من الاستخدام إلى · ( قطع، ثتوزع بين أحياء

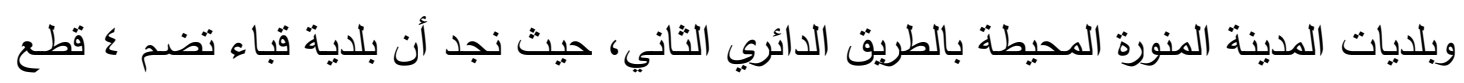
منها، بينما تضم بلدية العقيق ب قطع، يليها بلديـة العيون قطعتان، ثم بلدية أحد قطعة واحدة،

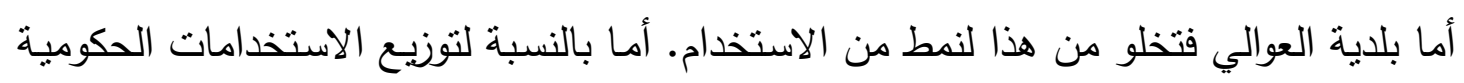
على الأحياء فنجد أنه أكثر انتشاراً حيث يتوزع على ^ أحياء من أحياء الطريق. فيلاحظ أن كل من حي بئر عثمان وحي العصبة يضم قطعتين من الأراضي، بينما نجد أحياء القصواء والوبرة والقبلتين والعنابس والروابي والثهداء تضم كل منها قطعة واحدة.

ك. المجمعات والمراكز التجارية: يضم هذا الاستخدام كل من المجمعات والمراكز التجاريـة الكبيرة والمتعددة الأنشطة، والتي بدأت تتنتر بمعظم مدن المملكة. والتي وجدت في أراضي الطريق الدائري الثاني مكاناً

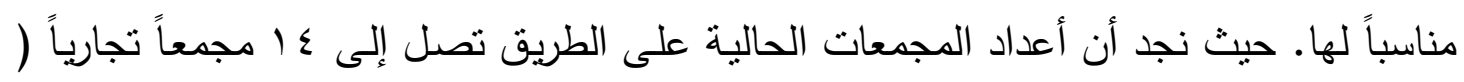




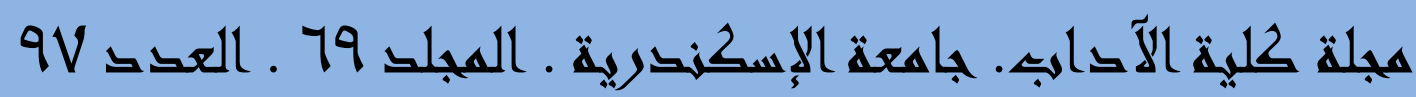

مول mall ) . وهذه المجمعات آخذة في الزيادة حيث نجد أن بعضـاً من المباني تحت الإنشاء هي في الواقع عبارة عن مجمعات تجاريـة مستقبلية، كما أن بعض الأراضـي الفضـاء الحاليـة مخصصة لمشاريع مجمعات تجارية في المستقبل القربب. ويلاحظ أن مساحات الاستخدام تتراوح

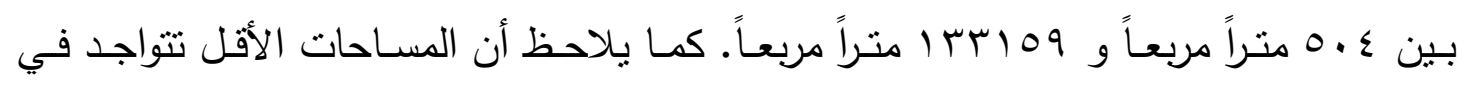
الأماكن القريبة من الكتلة العمرانية القديمة. أما المجمعات ذات المساحات الكبيرة فتتميز بحداثة النشأة وأنها بعيدة عن المناطق العمرانية القديمة بالمدينة المنورة ونلاحظ ذلك من الخربطة ( بانهة

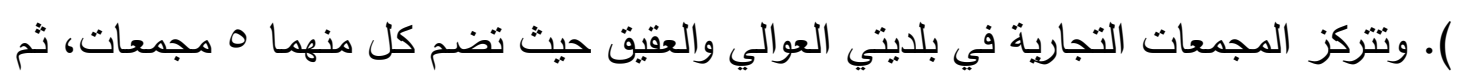

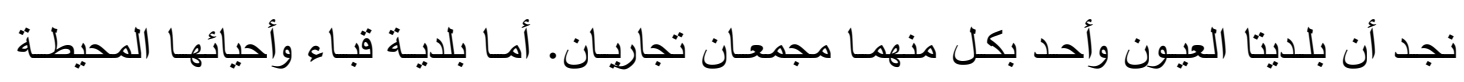
بالطريق فتخلو من المجمعات التجارية.

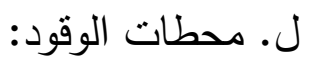

تعتبر محطات الوقود من أهم الاستخدامات على الطريق الدائري الثاني بالمدينة المنورة، سواء مـن حيث أعداد الأراضـي المستخدمة أو أهميته. فنجد أن أعداد محطسات الوقود على الهى

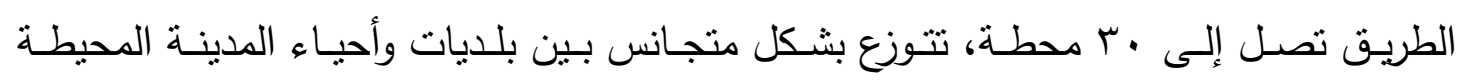
بالطريق. حيث نجد أن بلدية العوالي تضم • 1 محطات، تليها بلدية قباء V محطات، أما بلدية العقيق فتضم 7 محطات ثم بلدية العيون r محطات، وأخيراً بلدية أحد فتضم محطة واحدة. أما لها توزيع المحطات على مستوى الأحياء فنجد أن حي الظاهرة يضم 7 محطات، ثم حي القبلتين ؛ محطات، وأحياء العريض ومهزوز فبكل منها ب محطات، وأحياء بني حارثة والراية وشظاة بكل

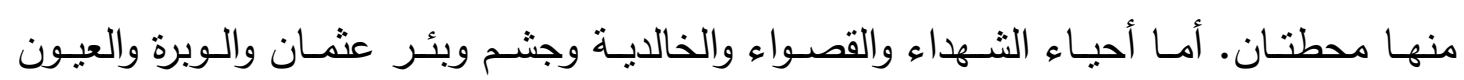
والأصيفرين فبكل منها محطة واحدة.

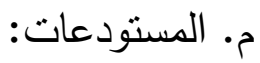

توجـد مجموعـة مـن المسـتودعات على الطريـق الـدائري الثاني، والتـي تصـل إلى 9

مستودعات، وهذا العدد آخذٌ في التناقص لتغير وظيفة الأراضي على الطريق الدائري الثاني. فقد كانت المسـتودعات هي الوظيفـة الرئيسية للأراضـي على الطريـق، وذلك قبـل اكتمـال مشـروع تطوير وتتمية المنطقة المركزية بالمدينة المنورة. ونتيجة لهجرة كثير من الأنشطة الاقتصادية من المنطقة المركزيـة، بالإضـافة إلى هجرة السكان نحو الأطراف، تغيرت وظيفة أراضـي الطريـق الدائري الثاني.

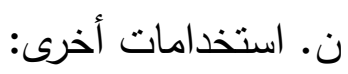




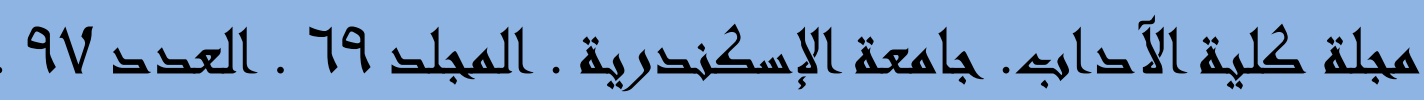

توجد مجموعة أخرى من الاستخدامات التي تحتل أراضي الطريق الدائري الثاني، ولكنها

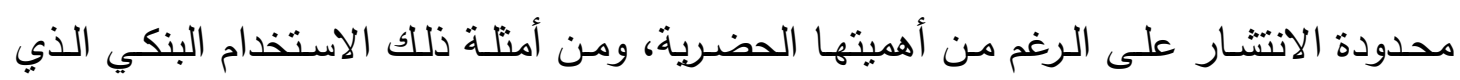
يشـخل قطعـة أرض واحدة كاستخدام مستقل، أمـا الاستخدام الترويحي فيتمثنل في الكافتيربـات والمقاهي ومقاهي الانتزنت وصسالات البلياردو حيث نجد أن أعداد الأراضي التي تمارس هذه الأنشطة أو الوظائف تتمثل في ع فقط، أمسا الاستخدام الاجتماعي والذي يتمثل في الخدمات الاجتماعية والخيرية وقاعات الأفراح والمناسبات فتوجد ؛ منها على الطريق الدائري الثاني. كما توجد بعض الأراضـي التي تمـارس الوظيفة الزراعيـة وعددها قطعتان، كما يوجد عدد تمارس أنشطة غير واضحة.

r- معيار طبيعة الإشغال:

يقصد بهذا المعيار حالة الأرض من حيث عدد الاستخدامات الموجودة عليها، وقد أمكن تحديد ثلاثة أنواع من الاستخدامات أو الاستغلال في الطريق، بالإضـافة إلى الأراضي الخالية (الفضاء) والأراضي تحت الإنشاء.

ا. قطع أحادية الإشغال.

يمنل الاستخدام الأحادي أكثر الاستخدامات شيوعاً على أراضي منطقة البحث، حيث تصل إلى 9 \& قطعة تتفاوت فيما بينها في نمط الاستخدام، ولكن معظمها عبارة عن استخدام سكني وتجاري. وتتباين بلديات المدينة المحيطة بالطريق الدائري فيما تضمه من أراضي هذا النمط، حيث نجد أن بلدية العوالي تضم 90 قطعة تمنل حوالي هب \% من أعداد قطع هذا النمط. يليها بلديـة قباء 0 قطعة، ثم بلديات أحد والعقيق بأعداد م ب ، VT قطعة بالتزتيب، وتأتي أخيراً

بلدية العيون حيث توجد بها 9 ا قطعة فقط.

جدول ( 0 ) توزيع الأراضي حسب طبيعة الإشغال

\begin{tabular}{|c|c|c|c|c|c|c|}
\hline الإجمالي & متعدد & ثنائي & أحادي & تحت الإنشاء & فضاء & الاستخدام \\
\hline$\wedge \wedge \mathrm{r}$ & VV & IrA & $r \leq q$ & $\varepsilon 1$ & TVA & عدد الوحدات \\
\hline
\end{tabular}

ب. قطع ثنائية الإشغال.

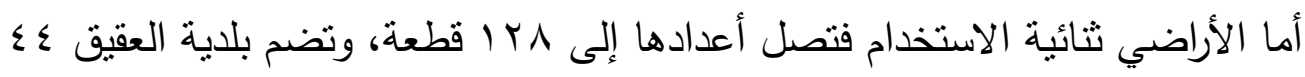

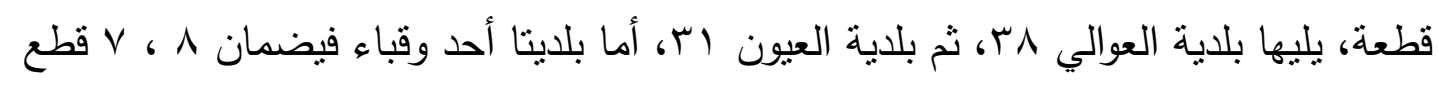




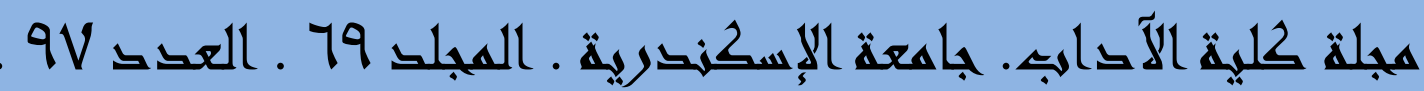

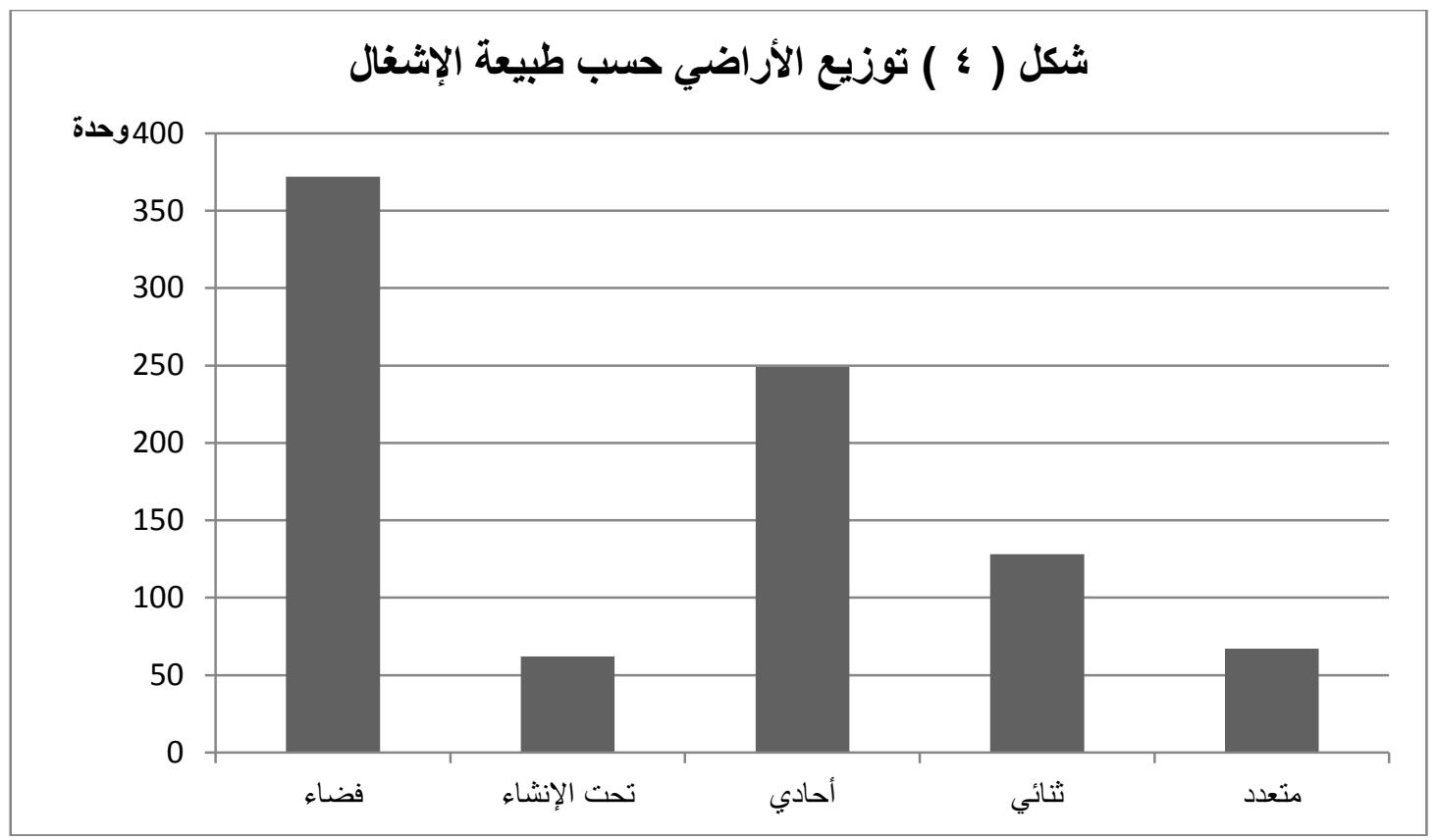

ج. قطع متعددة (مركبة ) الإتشال.

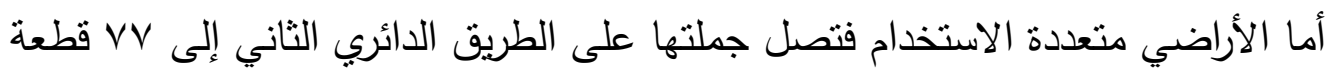

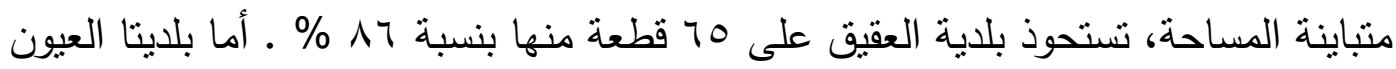
والعوالي فيوجد داخل كل منها 9 قطع، بينما نوجد قطعتان في بلدية قباء وقطعة واحدة ببلدية

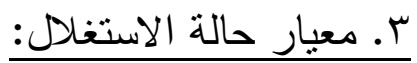

ويقصد به حالة الأراضي من حيث الاستغلال، ويمكن تقسيمها بناءً على ذلك إلى ما يلي:

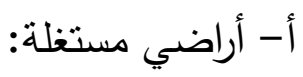

وهي الأراضي المستغلة بأي شكل من أنثكال الاستغلال المتعددة، سواء كانت أراضي أنسي

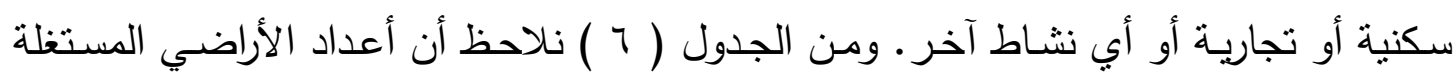

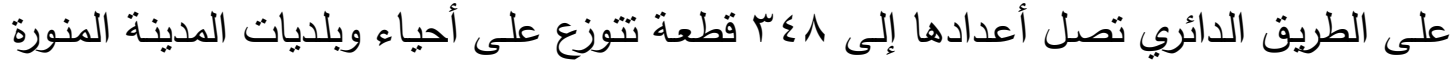

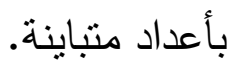

جدول ( 7 ) توزيع الأراضي حسب حالة الاستغلال

\begin{tabular}{|c|c|c|c|c|c|}
\hline الإجمالي & فضاء & تحت الإنشاء & غير مستغلة & مستظلة & حالة الاستغلال \\
\hline NAr & rVA & $\leqslant 1$ & Tro & $r \leqslant \wedge$ & عدد الوحدات \\
\hline
\end{tabular}




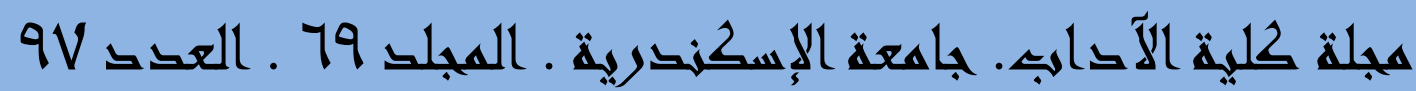

\section{شكل ( • ) توزيع الأراضي حسب حالة الاستغلال}

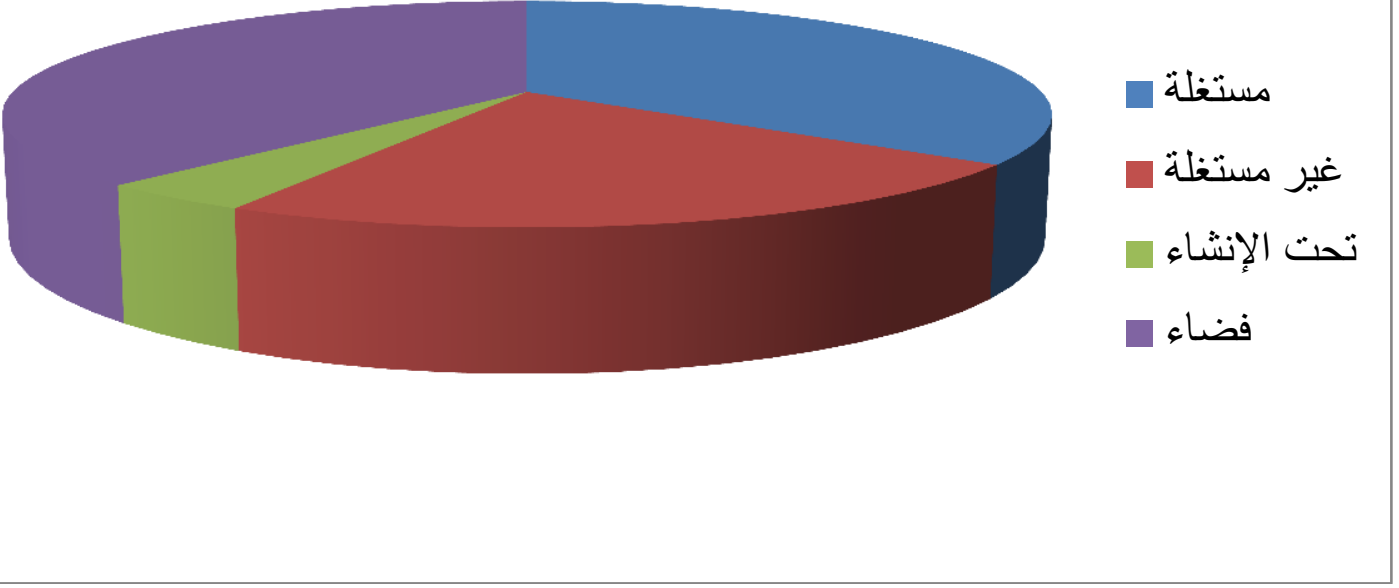

ب- - (أراضي غير مستغلة.

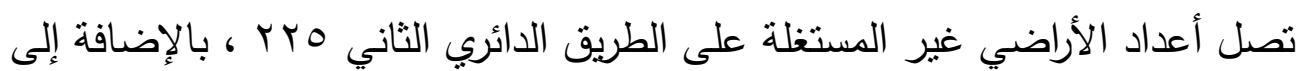
rT تحت الإنشاء لم تتحدد بعد وظيفتها أو نشاطها كما يتضح ذلك من الجدول ( 7 )، وتتباين هذه الأراضي في خصائصها المورفولوجية والجيولوجية، ولعل أتساع المساحة وظهور بعض بلاء الطفوح البركانية على سطح هذه الأراضي هو العامل الحاسم في عدم أو تأخر استخلالها حتى الوقت الراهن. ونتركز هذه القطع في بلدية قباء والعقيق بالمدينة المنورة.

جدول ( V ) توزيع الأراضي ببلديات المدينة المنورة حسب حالة الاستغلا

\begin{tabular}{|c|c|c|c|c|c|c|}
\hline الإجمالي & قباء & أحد & العيون & العوالي & العقيق & البلدية \\
\hline$\Gamma \leqslant \Lambda$ & 70 & $\leqslant \wedge$ & 00 & $1 \leqslant Y$ & r & مستغلة \\
\hline$r Y \leq$ & $\varepsilon$ & rA & 10 & 149 & $\varepsilon \wedge$ & غير مستغلة \\
\hline OVY & 79 & $V T$ & $V \cdot$ & rvi & 17 & الإجمالي \\
\hline
\end{tabular}

من الجدول ( V ) يتضح أن بلدية العوالي تستأثر بحوالي • ع \% من أراضي هدا النمط، يليها بلدية العقيق ثم بلدية أحد، بينما تحتل بلديتا قباء المرتبة الأخيرة وبلدية العيون المرتبة قبل الأخيرة. 


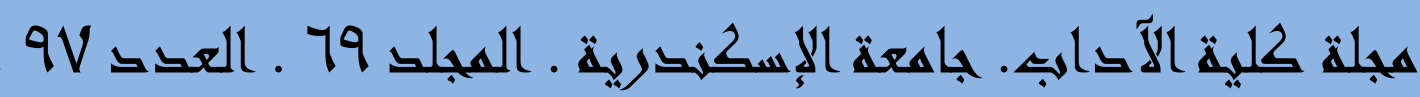

ع. معيار المساحة:

من خلال الجدول ( 1 ) نلاحظ ما يلي:

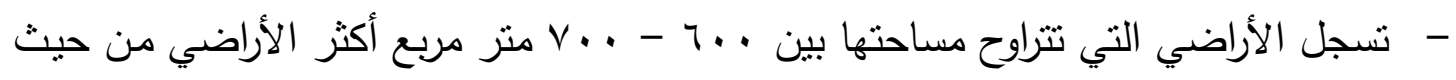

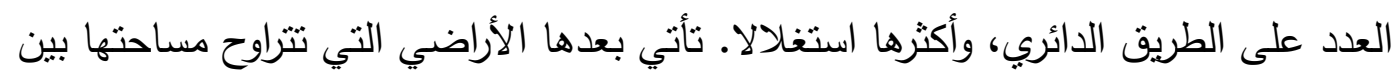

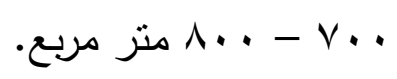

- أمسا الأراضـي محدودة المساحة الأقل من ـ . . 1 متر مربع فتصل أعدادها على الطريق

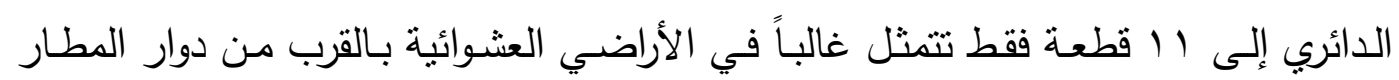
ودوار الملك عبد العزيز ببلدية أحد.

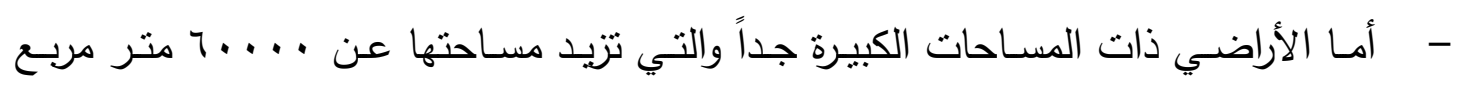

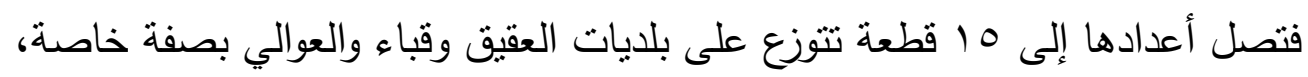

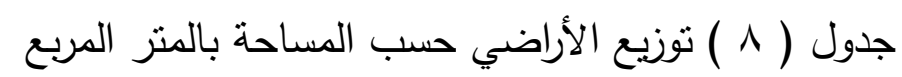

\begin{tabular}{|c|c|c|c|c|c|}
\hline العدد العد & المساحة & العدد العد & المساحة & العدد العد & المساحة \\
\hline r & $q \ldots-\wedge \ldots$ & 0 & $10 \ldots-1 \leqslant \ldots$ & 11 & أقل من . . \\
\hline 7 & $1 \ldots-9 \ldots$ & $\varepsilon$ & $17 \ldots-10 \ldots$ & 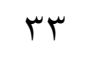 & $r \ldots-1 \ldots$ \\
\hline r & $10 \ldots-1 \ldots$ & 7 & $18 \ldots-17 \ldots$ & $\leqslant 9$ & $r \ldots-r_{\ldots}$ \\
\hline 11 & $r \ldots .10 \ldots$ & 1 & $11 \ldots-18 \ldots$ & $\varepsilon 1$ & $\varepsilon \ldots-r \ldots$ \\
\hline$\varepsilon$ & $r_{0} \ldots-r_{\ldots} .$. & 0 & $19 \ldots-11 \ldots$ & rq & $0 \ldots-\varepsilon \ldots$ \\
\hline$\varepsilon$ & $r_{\ldots} . . .-r_{0} \ldots$ & $\varepsilon$ & $r \ldots-19 \ldots$ & $\vee \wedge$ & $7 \ldots-0 \ldots$ \\
\hline r & ro... - r... & re & $r_{0} \ldots-r_{\ldots}$. & $1 \cdot 1$ & $\vee \ldots-1 \ldots$ \\
\hline r & $\varepsilon \ldots$. - ro... & 17 & r... - ro.. & 10 & $\Lambda_{\ldots} . v_{\ldots}$ \\
\hline r & $\leq 0 \ldots-\leq \ldots$ & Ir & ro... - r... & rq & $q \ldots-1 \ldots$ \\
\hline - & $0 \ldots \ldots-\leq 0 \ldots$ & $1 \varepsilon$ & $\varepsilon \ldots-r_{0} \ldots$ & 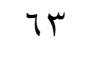 & $1 \ldots-9 \ldots$ \\
\hline . & $00 \ldots-0 \ldots$ & IV & $0 \ldots-\varepsilon \ldots$ & or & $11 \ldots-1 \ldots$ \\
\hline r & $7 \ldots-00 \ldots$ & ir & $7 \ldots-0 \ldots$ & r & $1 r \ldots-11 \ldots$ \\
\hline 10 & أكثر من . . . . & 1. & $v \ldots-7 \ldots$ & IV & Ir.. \\
\hline- & & 7 & $\wedge \ldots-\gamma_{\ldots}$. & ir & $1 \leq \ldots-1 \Gamma \ldots$ \\
\hline$\wedge \wedge \mathrm{r}$ & $\vee \varepsilon$ & $1 \leq 0$ & - & TTY & - \\
\hline
\end{tabular}

ه. معيار الارتفاع ( عدد الطوابق ).

يمكن تصنيف الأراضي بالطريق الائري الثاني حسب الإب عدد الطوابق إلى: 


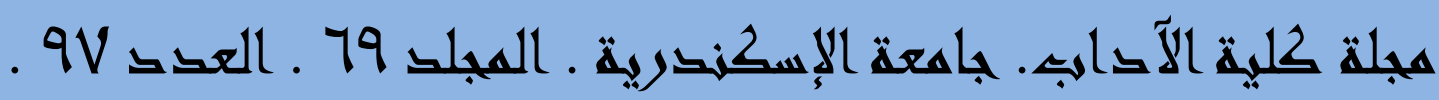

$$
\text { أ- أراضي ذات طابق واحد: }
$$

وتصل أعداد هذه القطع إلى وبى إقطعة تتنتر بأحياء وبلديات المدينة كما يتضـح من

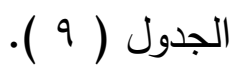

جدول ( 9 ) توزيع الأراضي حسب عدد الطوابق

\begin{tabular}{|c|c|c|c|c|c|c|c|c|c|c|c|c|}
\hline \multirow{2}{*}{ الإجمالي } & \multirow{2}{*}{ فضاء } & \multirow{2}{*}{ الإنشاء } & \multicolumn{9}{|c|}{ عدد الطوابق } & \multirow{2}{*}{ البيان } \\
\hline & & & 11 & $\wedge$ & V & 7 & 0 & $\varepsilon$ & $\mu$ & r & 1 & \\
\hline ANY & TVA & $\leqslant 1$ & V & 0 & $Y \varepsilon$ & $\mu$. & 01 & rY & Nr & 94 & 119 & عدد \\
\hline
\end{tabular}

ب- أراضي ذات طابقين.

تصـل أعداد هذه الأراضـي به قطعـة تتوزع بين بلديات المدينـة المنورة، حيث تسـأثز بلديـة العوالي بحوالي هب\% منها، يليها بلدية العقيق بحوالي . ب \%، أمسا بلديات العيون وأحد وقباء فيوجد بها تقريباً . 1\% بكل منها.

$$
\text { ج- أراضي مكونة من ب - ع طوايق. }
$$

تصل أعداد الأراضي المكونة من ب طوابق إلى بم قطعة، تتركز في بلدية العوالي حيث نتنأثز بحوالي • 0\% منها، يليها بلديتا العقيق وقباء بحوالي ابr\% لكل منها، أما بلديتا أحد والعيون فتقل بها المباني ذات الطوابث الثناثة بصورة واضحة كما يتضح من الجدول ( • ( ). أما بالنسبة لأعداد الأراضي المكونة من ع طوابق فتصل إلى بr قطعة ، تتوزع بين بلديات وأحياء المدينة

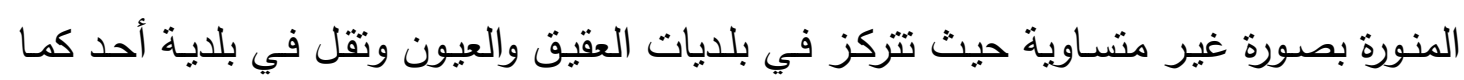

يتضح من الجدول ( ( ). 


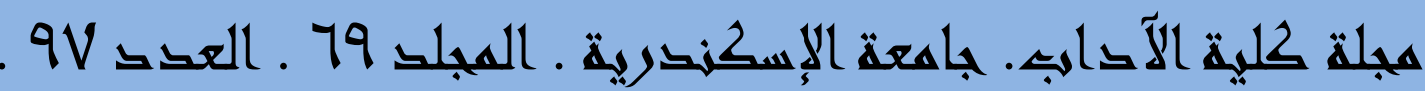

$$
\text { شكل ( " ) توزيع الأراضي حسب عدد الطوابق }
$$

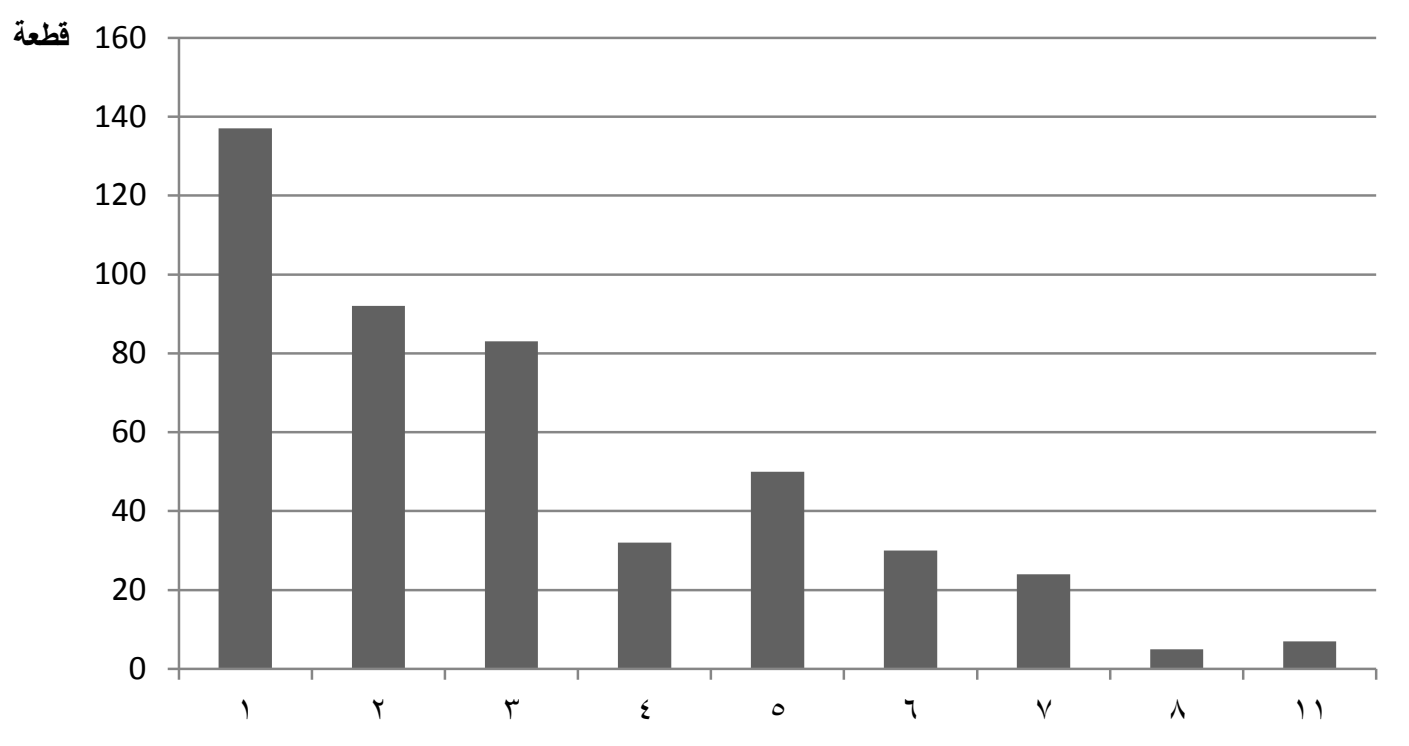

د- أراضي مكونة من 0 طوابق فأكثر .

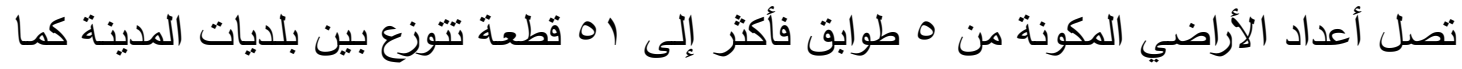
يوضحها جدول ( · ( ). حيث تتركز في بلدية العقيق وتقل بصورة واضحة في بلديتي قباء

جدول ( • ( ) توزيع الأراضي حسب عدد الطوابق ببلديات المدينة المنورة

\begin{tabular}{|c|c|c|c|c|c|c|}
\hline الإجمالي & قباء & أحد & العيون & العوالي & العقيق & البلدية \\
\hline 149 & r & YV & 9 & 01 & rq & طابق واحد \\
\hline 94 & 1. & 9 & 9 & rv & r^ & طابقين \\
\hline$\Delta r$ & IV & 7 & 1 & $\varepsilon r$ & IV & r طوابق \\
\hline rr & 0 & r & 1. & 0 & 1. & ع طوابق \\
\hline 01 & 1 & $\cdot$ & 0 & 11 & rV & ه طوابق \\
\hline$r$. & . & $\cdot$ & $r$ & $\wedge$ & 19 & 1 \\
\hline$r \varepsilon$ & . & $r$ & $\varepsilon$ & r & 10 & طوابق V \\
\hline 0 & . & $\cdot$ & 0 & . & . & ^ طوابق \\
\hline v & . & $\cdot$ & 0 & . & r & Iا طابق \\
\hline$\varepsilon\rceil \varepsilon$ & $7 \varepsilon$ & $\leq 7$ & 01 & $17 \varepsilon$ & $10 \mathrm{~V}$ & الإجمالي \\
\hline
\end{tabular}




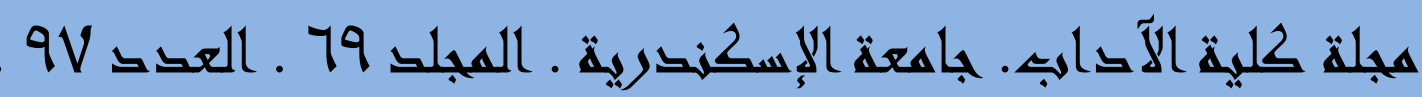

$$
\text { 7. - معيار طريقة الإنشاء: }
$$

يمكن تصنيف الأراضي حسب معيار طريقة الإنشاء بالطريق الدائري كما تتضح بالجدول

$$
\text { (1) }
$$

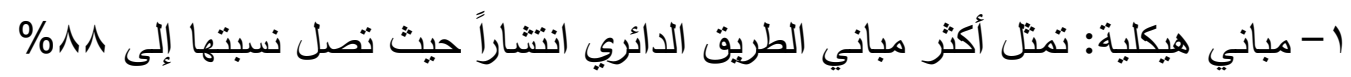

$$
\text { تقريباً من إجمالي المباني على الطريق الدائري. }
$$

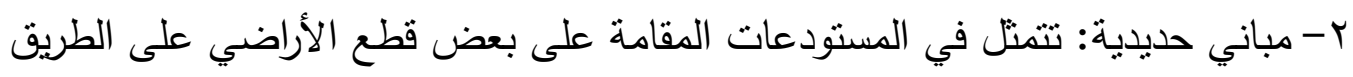

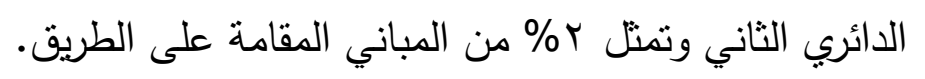

\begin{tabular}{|c|c|c|c|c|c|}
\hline الإجمالي & فضاء & شعبي & حديدي & هيكلي & الحالة \\
\hline$\Lambda \wedge r$ & rVA & 01 & 1. & $\leqslant \leqslant 0$ & العدد \\
\hline
\end{tabular}

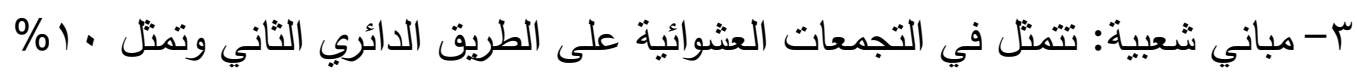

من مباني الطريق.

جدول ( 11 ) نوزيع الأراضي حسب طريقة الإنشاء

\begin{tabular}{|c|c|c|c|c|c|c|}
\hline الإجمالي & قباء & أحد & العيون & العوالي & العقيق & البلدية \\
\hline$\leqslant \leqslant 0$ & $\varepsilon r$ & rTr & 01 & $19 V$ & $1 \mu$. & هيكلي \\
\hline 1. & 7 & 1 & 1 & r & - & حديدي \\
\hline 01 & 17 & $r \varepsilon$ & 1 & r & V & شعبي \\
\hline 0.7 & 70 & $\leqslant \wedge$ & or & $r \cdot r$ & ITV & الإجمالي \\
\hline
\end{tabular}

وتتوزع الأراضي بين بلديات المدينة المنورة كما تتضح من الجدول ( r ا )، حيث تضم بلدية

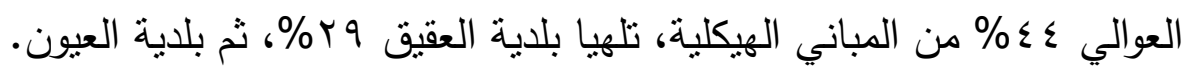

أما المباني الحديدية فنجد أن بلدية قباء تضم أكثر من هذه المباني. أما المباني الثعبية فيتركز وجودها في بلدية أحد حيث تضم تقريباً . 0\% منها، تليها بلدية قباء ثم بلدية العقيق. 


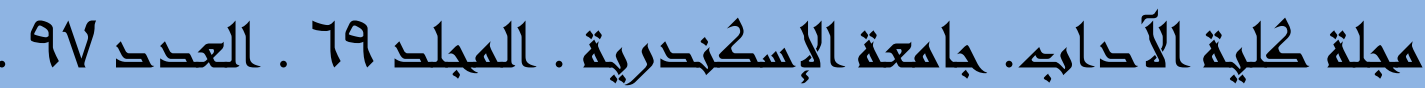

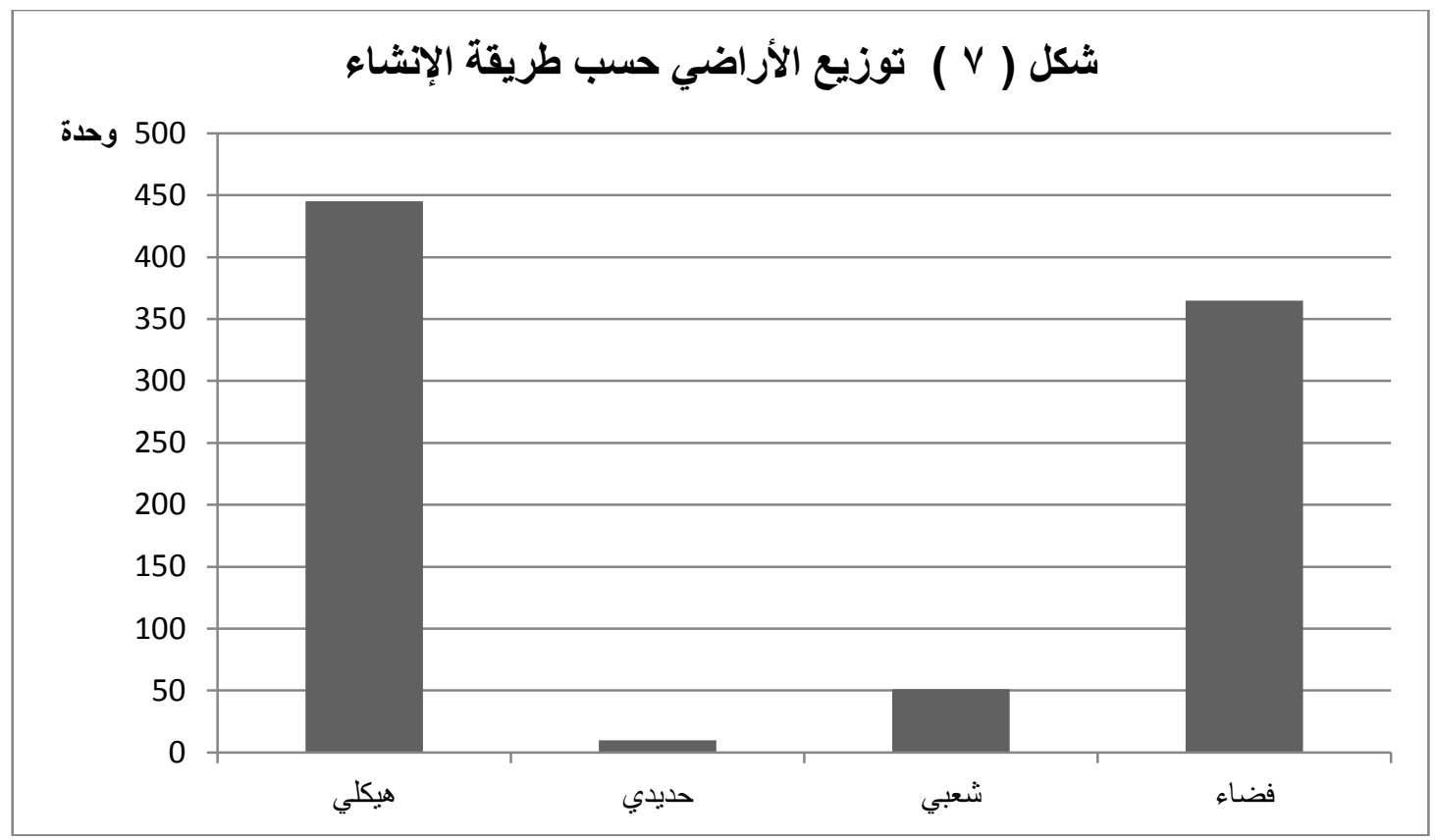

- - معيار الملكية:

يمكن تصنيف أراضي الطريق الدائري الثاني بالمدينة المنورة حسب معيار الملكية كما يوضحه جدول ( آ إ ) إلى نمطين هما:

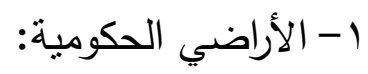

يلاحظ أن هذا النمط من الملكية محدود على الطريق الدائري الثاني بالمدينة المنورة

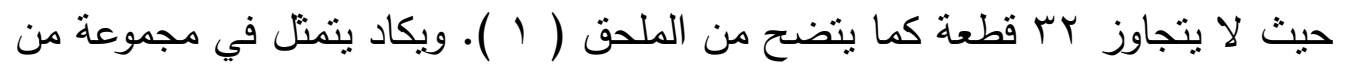

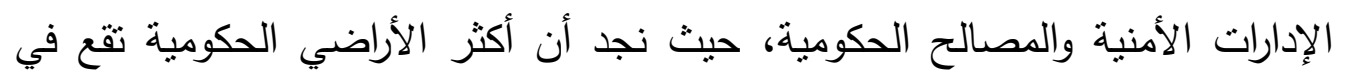

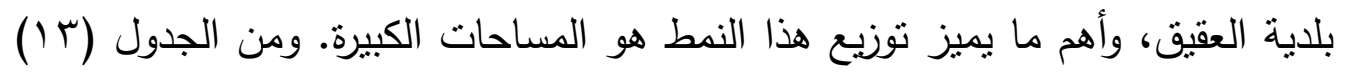

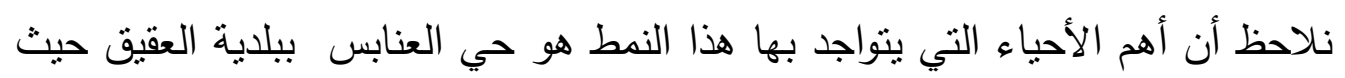
توجد مصلحة المياه، وإدارة مكافحة المخدرات. r- الأراضي الخاصة ( الأهلية ):

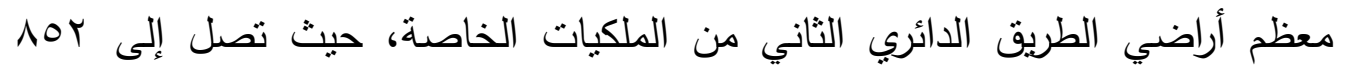

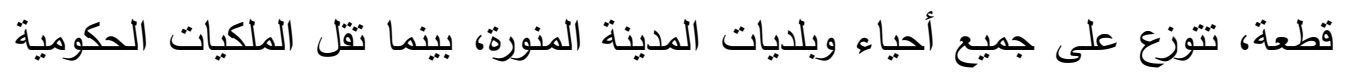
والتي تكاد تتحصر في بعض إدارات الأمن ومصلحة المياه بالمدينة المنورة، كما يتضح

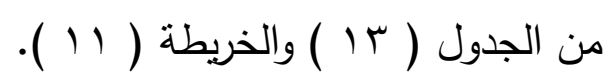




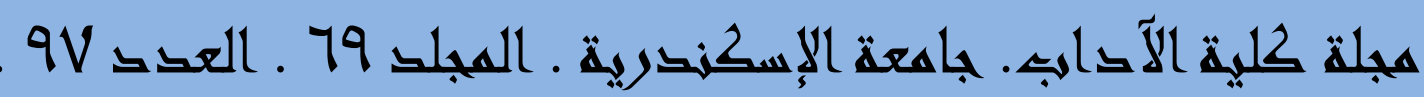

أما من حيث نوزيع الأراضي بالطريق الدائري الثاني حسب الملكية على مستوى بلديات المدينة المنورة المحيطة به، فنجد أن بلدية العوالي تمثل أكثر البلديات استحواذاً على الأراضي الخاصة أو الملكيات الأهلية، ثليها بلدية قباء ثم بلدية العقيق. جدول ( r ) توزيع الأراضي ببلديات المدينة المنورة حسب الملكية

\begin{tabular}{|c|c|c|c|c|c|c|}
\hline الإجمالي & قباء & أحد & العيون & العوالي & العقيق & البلدية \\
\hline Nor & r) 9 & V. & $7 \varepsilon$ & TrV & 187 & ص ص \\
\hline r & $\Lambda$ & 7 & 0 & 0 & 1. & حكومي \\
\hline ANY & YrV & $V T$ & 79 & ץTr & 117 & \\
\hline
\end{tabular}

ومن جدول ( ع ا ) الذي يوضح مصفوفة الارتباط لبعض المتغيرات لأراضي الطريق الدائري الثاني بالمدينة المنورة نلاحظ ما يلي: - يوجد ارتباط عكسي ضعيف بين مساحة الأراضي بالطريق الدائري وبين مجموعة المتغيرات مثل نمط النشاط وطريقة الإنشاء وطبيعة الاستغلال وكذلك عدد الطوابق تراوح بين $\cdot(\cdot .0-6 \cdot .+5-)$

جدول ( \& 1 ) مصفوفة الارتباط لبيانات الطريث الدائري الثاني بالمدينة المنورة

\begin{tabular}{|c|c|c|c|c|c|c|}
\hline طبيعة الاستغلال & عدد الطوابق & طريقة الإنشاء & نمط النشاط & المساحة & رقم القطعة & المتغير \\
\hline & & & & & 1.00 & رقم القطعة \\
\hline & & & & 1.00 & -0.04 & المساحة \\
\hline & & & 1.00 & -0.05 & 0.22 & نمط النشاط \\
\hline & & 1.00 & 0.80 & -0.05 & 0.15 & طريقة الإنثاء \\
\hline & 1.00 & 0.69 & 0.80 & -0.04 & 0.25 & عدد الطوابق \\
\hline 1.00 & 0.66 & 0.91 & 0.82 & -0.04 & 0.22 & طبيعة الاستغلال \\
\hline
\end{tabular}

- أما بالنسبة لنمط النشاط فيوجد ارتباط قوي جداً بينه وبين طريقة الإنشاء بلغ ـ ـ. •، كما بلغ الارتباط بينه وبين طبيعة الاستغلال إلى rی . •، وكذلك وجد ارتباط قوي موجب بين

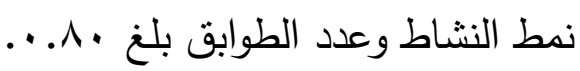

- أما بالنسبة لطبيعة الاستغلال فيوجد ارتباط قوي جداً وموجب مع طربقة الإنشاء بلغ و . . ، كما وجد ارتباط قوي موجب بينه وبين عدد الطوابق بلغ 7 . . . - أما بالنسبة لطريقة الإنشاء فيوجد ارتباط موجب قوي بينها وبين عدد الطوابق بلغ 99 . . . 


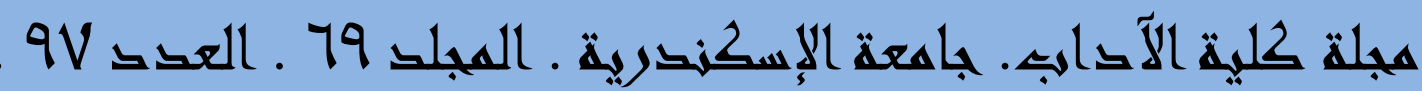

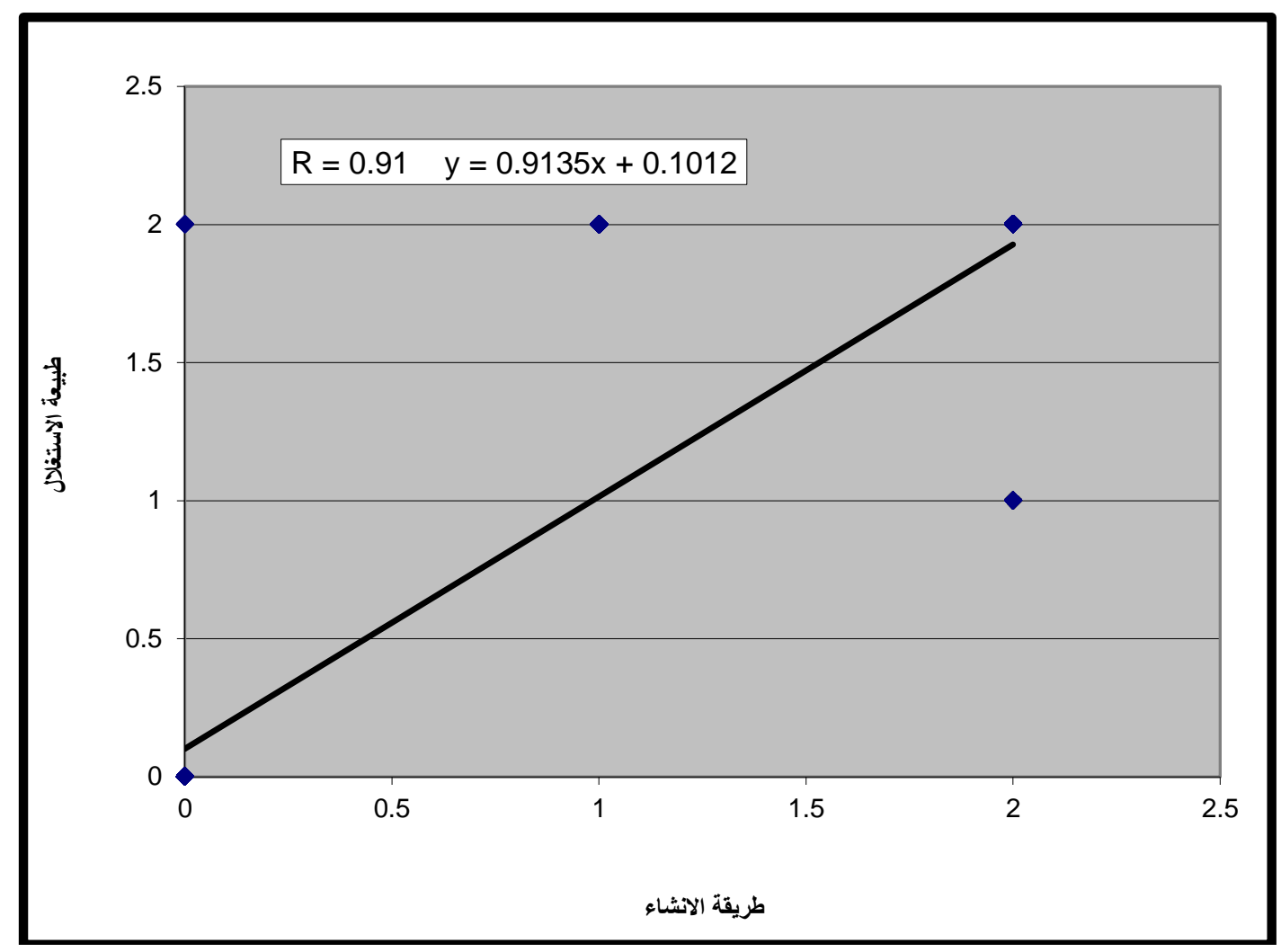

شكل ( A ) العلاقة بين طريقة الإنثاء وطبيعة الاستغلال

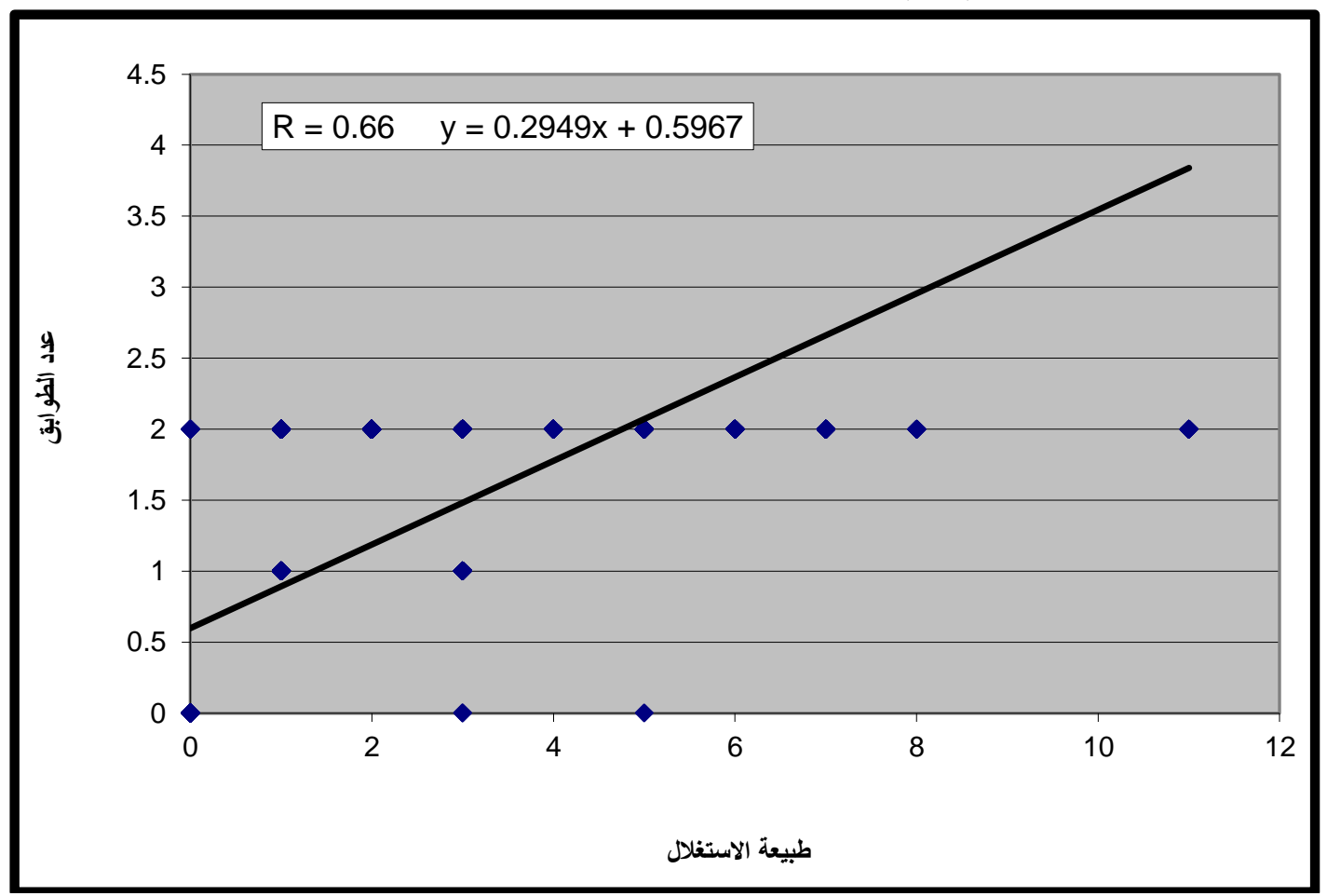

شكل ( 9 ) العلاقة بين طييعة الاستفلال وعدد الطوابق 


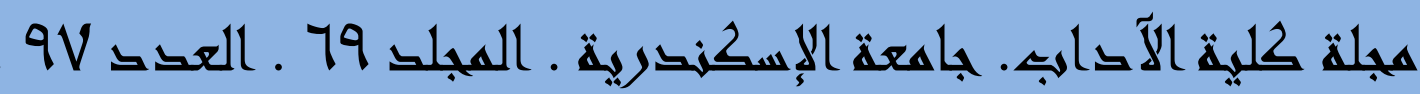

ومما سبق يمكن أن نستخلص ما يلي: - - يؤثر قانون تنظيم المباني بالمدينة المنورة على خصائص الم المباني واستخدامات الأراضي

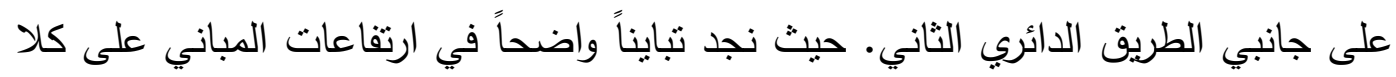

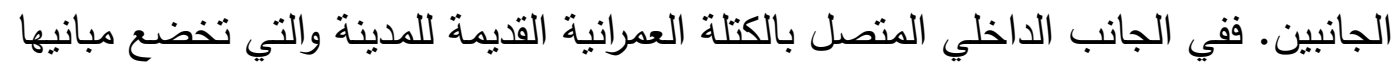

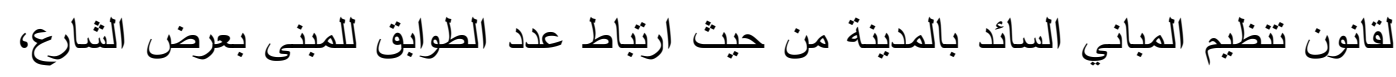

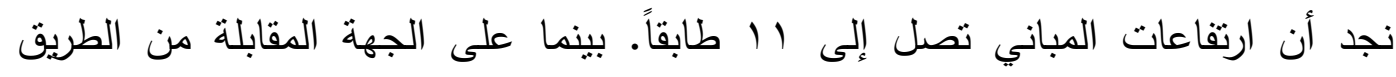

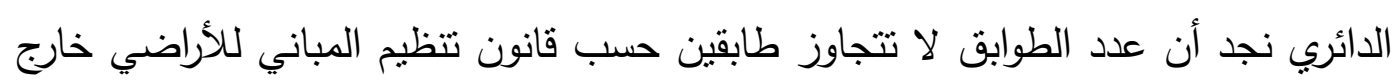
الطريق الدائري.

- - يتأثر استخدام الأرض على جانبي الطريق بعاملين أساسيين هما أسعار الأراضي

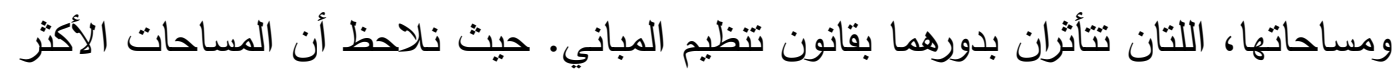

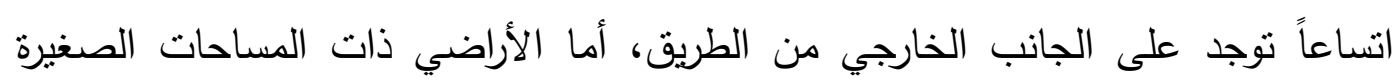

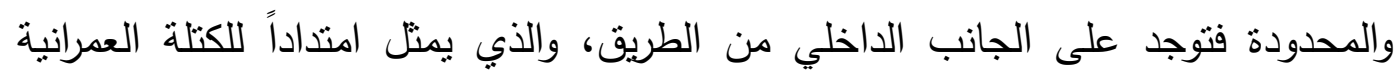
القديمة للمدينة المنورة. ولذا حدث تجمع وتركز للمجمعات والمراكز التجارية والمستودعات التي تحتاج إلى مساحات كبيرة لنشاطها على هذا الجانب من الطريق، بينما تركز الاستخدام السكني والخدمات الثخصية على الجانب الداخلي من الطريق.

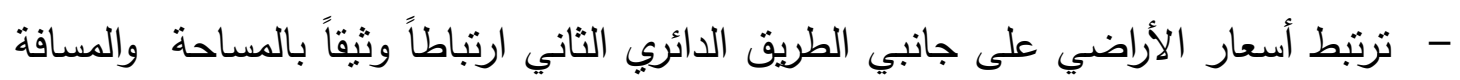

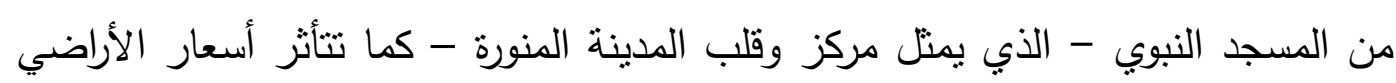

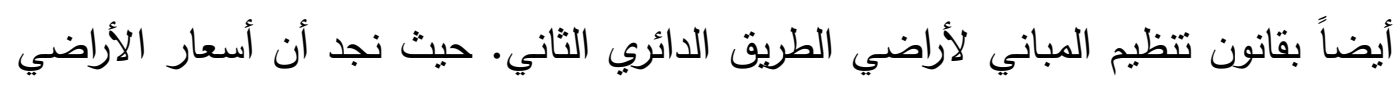
على الجانب الداخلي من الطريق نزيد عن أسعار مثنيلاتها على الجهة المقابلة.

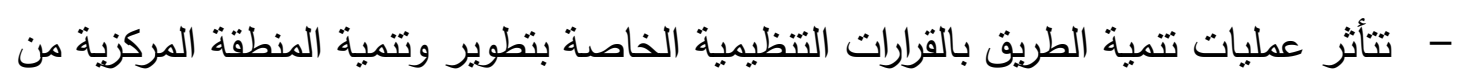

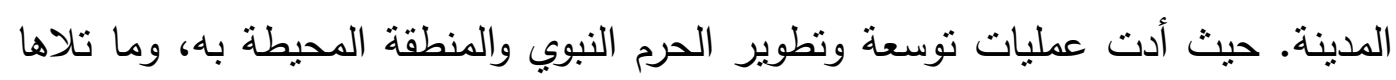

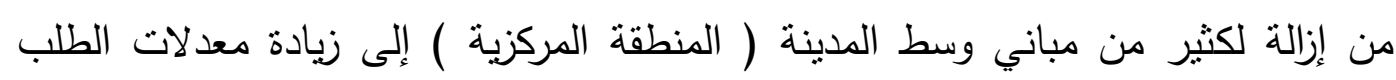

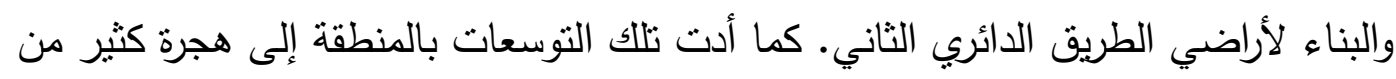

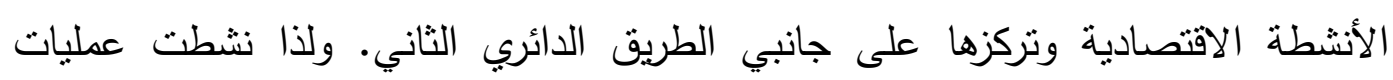

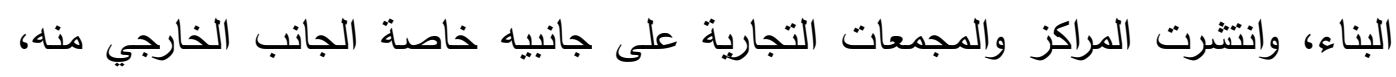

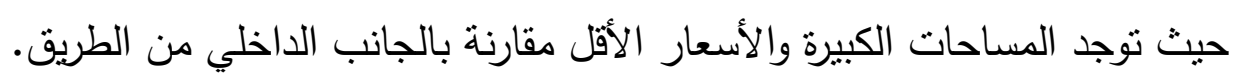

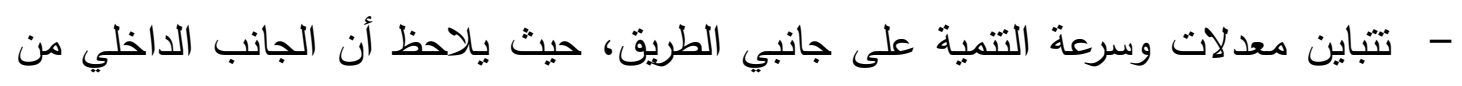

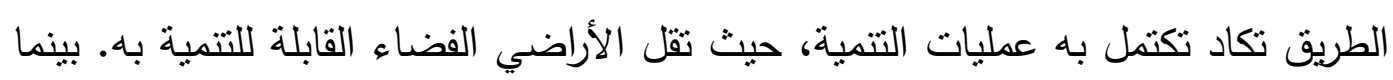

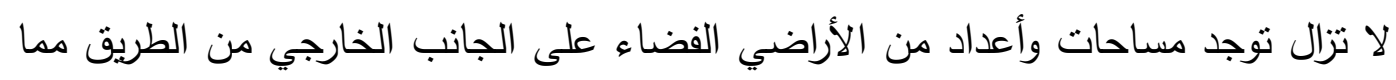

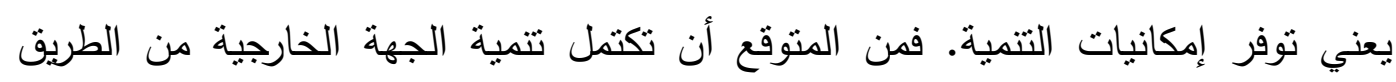




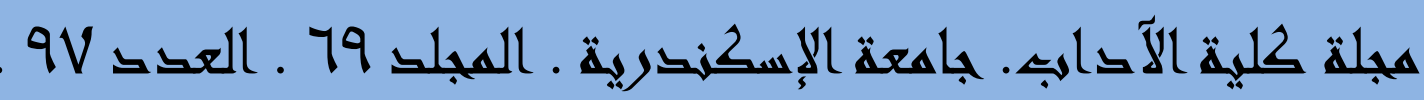

وتختفي الأراضي الفضاء به خلال السنوات العثر القادمة. حيث تهاجر كثير من الأنشطة التجارية من مركز المدينة ومن مواقعها التقليدية في الأحياء القديمة القريبة من المسجد النبوي نتيجة زيادة الطلب عليها وارتفاع أسعار الإيجارات بها لتتركز بمنطقة الدراسة. - تعتبر المناطق المحيطة بالطريق الدائري هي المناطق الأكثر استيعاباً لهجرة السكان والأنشطة في المدينة المنورة، لما تتمتع به من خصائص أهمها انخفاض أسعار الأراضي مقارنة بالمناطق الأخرى من المدينة وكذللك سهولة الوصول، وتركز كثير من المراكز والمجمعات التجارية به.

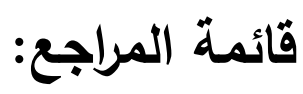

أولاًا : المراجع العربية : اكبية 1- الكتب والمصادر والدوريات:

ا- إبراهيم ، عبد الباقي ، . . بم ، "نحو نظرية جديدة في تتمية المجتمعات الحديثة" ، المدينة

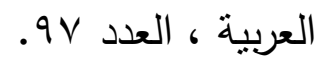

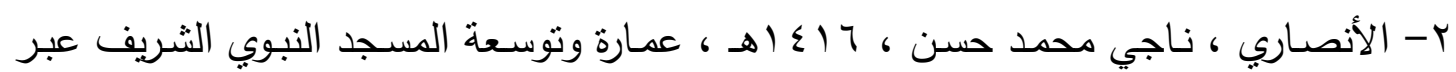
التاريخ ، نادي المدينة المنورة الأدبي ، رقم 90 ، الأبدين ، المدينة المنورة . ب- ابن النجار ، أبو عبد الله محمد بن محمود ، 1 • ع اهـ ، أخبار مدينة الرسول ، طس ، مكتبة الثقافة ، مكة المكرمة (تحقيق صالح محمد جمال) .

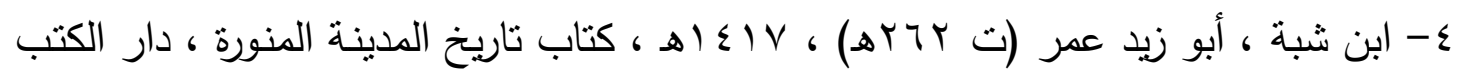

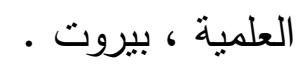

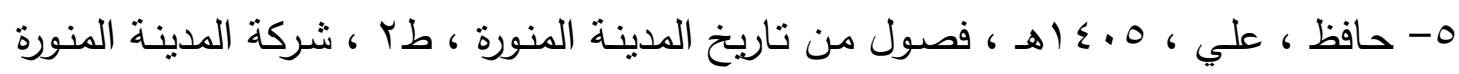
للطباعة والنشر ، جدة .

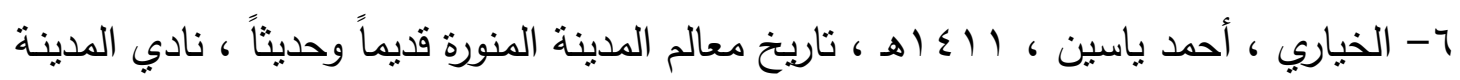
المنورة الأدبي ، رقم 9 ه ، المدينة المنورة (تعليق وتخريج عبيد الله محمد كردي) .

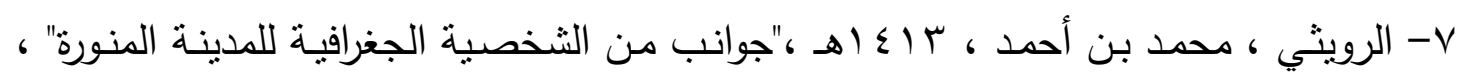

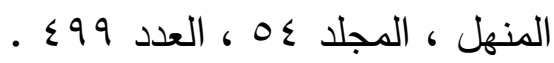

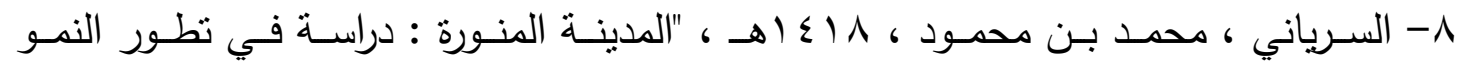
الحضـري" ، في الروبثتي ، محمد بـن أحمـد وخوجلي ، مصطفى محمد (محرران) ، المدينـة المنورة : البيئة والإنسان ، دار الواحة العربية ، المدينة المنورة . 
هجلة طلية الآدامبـ. باهعة الإسكنحرية ـ المجلد 79 ـ العقد 9V.

9- الســهودي ، نـور الدين ، بوس اهـ ، وفـاء الوفـاء بأخبـار المصطفى ، طץ ، دار إحيـاء التراث العربي ، بيروت .

• 1- طه ، حاتم عمر ، باءـ (هـ ،"ملامح من فن العمارة في المدينة المنورة" ، المنهل ، معـه ، عدد 99؟ . ع

ا ا- علي ، زيـن العابـين ، · بـ أهـ ، مبـادئ تخطيط النقل الحضـري ، دار صـفاء للنشـر

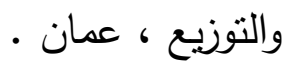
Y T - مكي ، محمد شوقي بن إبراهيم ، VI V أهـ ،"النمو العمراني وتأثيره على المعالم الحضـارية في المدينـة المنـورة" ، المدينـة العربيـة وتحديات المسـتقبل ، المعهد العربـي لإنمــاء المـدن ، • الرياض ب ا - مكي ، محمد شوقي بن إبراهيم ، 0 . ع اهـ ، سكان المدينة المنورة ،دار العلوم ، الرياض . ع ا - فرحات، عبد المحن محمود، وفدعق، طارق علي. نحو مبادئ متكاملة لتخطيط وتصميم المنطقة المركزية لمكة المكرمة. مجلة جامعة الملك عبد العزيز، العلوم الهندسية، مع، بو99 اهـ. ه - علي حافظ ، " فصول من تاريخ المدينة المنورة " طبع ونشر شركة المدينة المنورة للطباعة والنشر ، و جدة. 7 ا - محمد سعيد فارسي ، " التكوين المعماري والحضري لمدن الحج " طبع ونشر شركة عكاظ

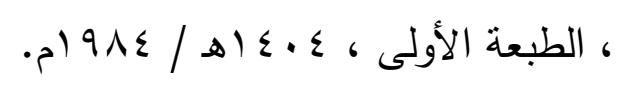
V V امد عباس ، " قصة التوسعة الكبرى " نشر مجموعة بن لادن السعودية ، الطبعة الأولى الهى . $1990 /$ ه 1517 ،

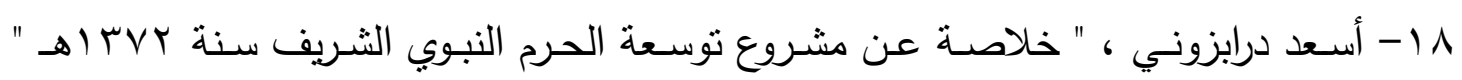

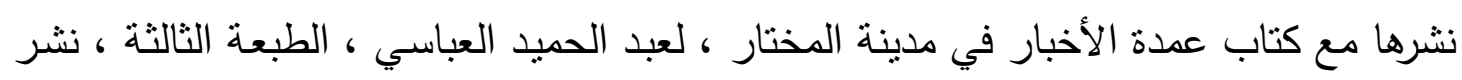
أسعد درابزوني.

9 ا - عبد القدوس الأنصـاري " آنثار المدينـة المنـورة " دار العلم ، بيـروت ، الطبعـة الثالثة ، - م) • ץ- صالح لمعي "المدينة المنورة تطورها العمراني وتراثها المعماري ، دار النهضة المصرية ،

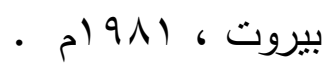

ا Y- محمد صالح البليهثي " المدينة المنورة " ، الطبعة الثانية ، الرياض ، 1 ، ـ ؛ اهـ . r - النشرات والتقاربير: 1- وزارة الثؤون البلدية والقروية، وكالة الوزارة لتخطيط المدن. تخطيط التتمية الثـامل لمنطقة

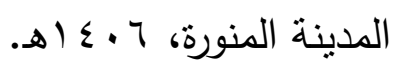




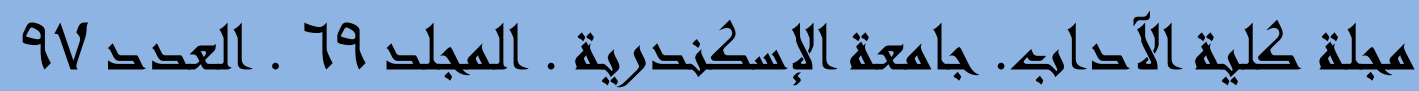

ץ- وزارة الثؤون البلديـة والقرويـة ، وكالـة تخطيط الدـدن ، أطلس المدن السـودية : النطـاق

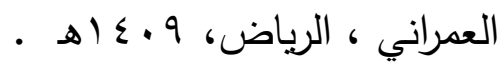

ب- وزارة الثؤون البلدية والقروية، وكالة الوزارة لتخطيط المدن. تخطيط التتمية الثـامل لمنطقة مكة المكرمة: منطقة الحرم الثريف. 7 • أهـ الهـ

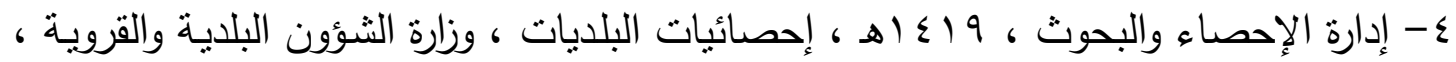

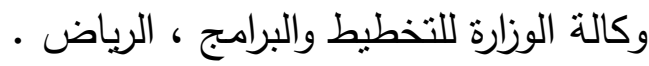

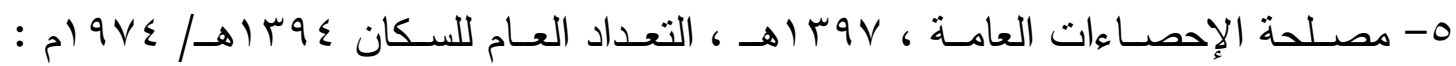
البيانات التقصيلية ـ منطقة المدينة المنورة ، وزارة المالية والاقتصاد الوطني ، الرياض .

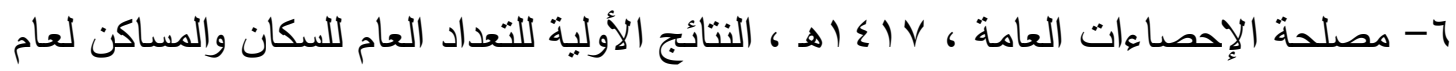

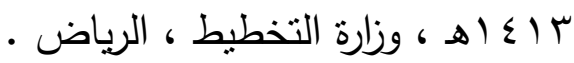
V V مصلحة الإحصاءات العامة ، V V ا أهـ ، النتائج الأولية للتعداد العام للسكان والمساكن لعام

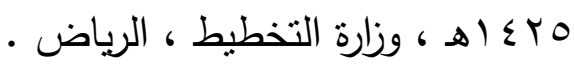
1- الرئاسة العامة لثشئون المسجد الحرام والمسجد النبوي. الحرمان الثريفان: التوسعة والخدمات خلال مائة عام. دار عكاظ للطباعة والنشر، 9 (أ أهـ

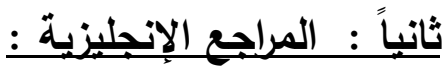

1- Bookchin, M .,1987 The Rise and Decline of Citizenship, -Sierra Club Books, San Francisco.

2- Cooper, D ., 1999, "Keeping an Eye on Nature", Durham -First, No .9.

Encyclopedia Britannica Co . Ltd ., 1929, Encyclopedia -Britannica,14th ed.

3- Losada, H ., et .,1998, "Urban Agriculture in the Metropolitan Zone of Mexico City :Changes over Time in Urban, Suburban and Peri-Urban Areas", Environment and Urbanization, Vol .10,No .2.

4- Makki, M .S ., 1982, Medina-Saudi Arabia : A Geographical Analysis of the City and Regions, Avebury, London.

5- Philby, H .St .J .B ., 1946, A Pilgrim in Arabia, Robert Hale Ltd ., London . H . st . J .B ., 1933, "Mecca and Medina", Jour . Of the Royal Central Asian Society, Vol .10. 6- Roth, G .,1999, "Combating Congestion with Cash", Urban Age, Vol .7,No.2. 


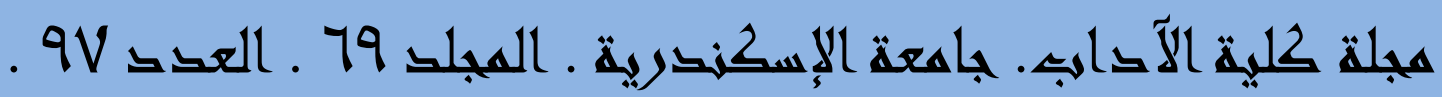

7- Biancha, Stefano Urban Form in the Arab World Thames and Hudson, New York, 2000.

8- Sendi, Munir Urban Development in Makkah: Urban Design and Development Guidelines for the Central Area Master of Architecture Thesis, University of Kansas, 1988

9- The World Bank World Development Report2000 Oxford University Press, New York, 2000

10- United Nations Center for Human Settlements (Habitat) Cities in a Globalizing World Earthscan Publications, London. 2001.

11- Fadaak,T and Farahat,A. The Challenges of the Haram District Urban Renewal Project . College of Engineering, King Abdul Aziz University Sponsored Research Project 1409 AH 1988 AD. 